\title{
Faiz Oranı Paritesi ve Etkin Piyasa Hipotezinin Gelişen Piyasa Ekonomileri İçin Test Edilmesi ${ }^{*}$
}

Faruk Mike ${ }^{1}$

Faiz Oranı Paritesi ve Etkin Piyasa Hipotezinin Gelişen Piyasa Ekonomileri İçin Test Edilmesi

\section{Öz}

Bu çalışmada faiz oranı paritesi ve etkin piyasa hipotezinin uzun dönemli geçerlilikleri 14 gelişen piyasa ekonomisi için 2003Q1-2015Q4 çeyreklik dönemler itibariyle test edilmektedir. Güvencesiz versiyonunun ele alındığı faiz oranı paritesi modeli için zaman serisi ve panel veri analizlerine yer verilmektedir. Yarı-güçlü versiyonun ele alındığı etkin piyasa hipotezi için ise zaman serisi analizine yer verilmektedir. Çalışmadan elde edilen bulgular, faiz oranı ve döviz kuru ilişkisini gösteren ve varlık piyasası koşullarını yansıtan faiz paritesi ile piyasa etkinliğinin genel olarak sağlanamadığına yöneliktir. Buna göre küresel finansal piyasalarda yaşanan olumsuzluklar, gelişen piyasa ekonomilerinin makroekonomik politikalarında meydana getirdiği değişiklikler nedeniyle, döviz kurlarının öngörülebilirliğinin azalmasına yol açmaktadır.

Anahtar Kelimeler: Güvenceli Faiz Oranı Paritesi, Güvencesiz Faiz Oranı Paritesi, Etkin Piyasa Hipotezi, Gelişen Piyasa Ekonomileri
Testing the Interest Rate Parity and Efficient Market Hypothesis for Emerging Market Economies

\section{Abstract}

In this study, the long-run validity of the interest rate parity and efficient market hypothesis is tested for quarterly periods 2003Q1-2015Q4 for 14 emerging market economics. Time series and panel data analysis were applied for the interest rate parity model which uncovered version was used. And time series analysis were applied for the efficient market hypothesis which semi-strong form was used. Findings from the current study showed us that interest rate parity, that explaining the relationship between interest rate and exchange rate and reflect the asset market conditions, and efficient market hypothesis does not hold for these countries. This leads to reduction in the foreseeability of exchange rates due to the negative effects of global financial markets that changes in macroeconomic policies of emerging market economies.

Keywords: Covered Interest Rate Parity, Uncovered Interest Rate Parity, Efficient Market Hypothesis, Emerging Markets

\section{Giriş}

Uluslararası finansal sermayenin küresel ölçekte serbest bir şekilde hareket edebilmesi, finansal piyasaların entegrasyon seviyesindeki artışlar sayesinde mümkün olabilmektedir. Günümüzde küresel yatırımcı olarak adlandırabilecek ekonomik karar birimlerinin, piyasalar arasında oluşabilecek kar fırsatı durumunda işlemlerini hızlı ve anlık olarak gerçekleştirebilmeleri bu gelişmenin bir sonucudur. Bu durum finansal piyasaların önemini yatırımcılar ve ekonomi politikası yapıcıları için her geçen gün arttırmaktadır.

Küresel piyasalarda faaliyet gösteren karar birimlerinin yatırım kararları verirken göz önünde bulundurdukları en önemli kriter "risk-getiri" ilişkisidir. Bilindiği üzere risk ile getiri arasında doğru yönlü bir ilişki bulunmaktadır. Yatırımcılar portföy tercihlerini yerli ve yabancı menkul varlıkların olası getirileri arasındaki karşılaştırmalar ile belirlemektedir. Bu anlamda yurtiçi faiz oranının yurtdışı faiz oranından daha yüksek olması yerli varlıkları, tersi durum ise yabancı varlıkları ön plana çıkarmaktadır. Ancak yabancı para birimine bağlı bir varlığa yatırım yapmaya

\footnotetext{
*Bu çalışma Çukurova Üniversitesi Sosyal Bilimler Enstitüsü Iktisat Anabilim Dalı’nda tamamlanan “Gelişen Piyasa Ekonomilerinde Uluslararası Parite Koşulları ve Piyasa Etkinliği" isimli doktora tezinden türetilmiştir. Katkılarından dolayı danışmanım Prof. Dr. Murat DOĞANLAR'a teşekkür ederim.

${ }^{1}$ Dr. Öğr. Üyesi, Hakkari Üniversitesi, ỉktisadi ve İdari Bilimler Fakültesi, ỉktisat Bölümü, farukmike@hakkari.edu.tr, https://orcid.org/0000-0002-9194-1679
} 
karar verildiğinde, döviz kurunun gelecekte değer kaybına yönelik muhtemel bir döviz risk ile karşılaşılabilmektedir (Ingham, 2004: 173).

Genel olarak yatırımcıların risksiz varlıkları riskli olanlara tercih ettiği kabul edilmektedir. Ancak bu durum ekonomik karar birimlerinin her zaman risk primi talep ettikleri anlamına gelmemektedir. Hiçbir karşılık beklemeden riskli varlıklara yönelen ve hatta risk taşıyan varlıklara ayrıcalık tanıyan karar birimlerinin yer aldığı örnekler de bulunmaktadır. Yatırımcı profili bu anlamda üç kısma ayrılmaktadır: Risk almaktan kaçınanlar, risk almaktan kaçınmayanlar ve riske karşı duyarsız olanlar (Copeland, 2005: 86-87).

Finansal varlıkların getirisi olan faiz ile döviz kurları arasındaki ilişkiyi açıklayan faiz oranı paritesi ve finans piyasalarının etkinlik dereceleri bu çalışmanın konusunu oluşturmaktadır. Çalışmada ilk olarak faiz oranı paritesi ve temel versiyonları olan güvenceli ve güvencesiz faiz paritesine değinilecektir. Güvencesiz faiz paritesi kapsamında risk priminin önemi açıklanmaya çaIışılacaktır. İkinci olarak piyasa etkinliği teorisi ve dereceleri açıklanacaktır. Etkin bir piyasa için gerekli olan iki temel varsayım üzerinde durulacaktır. Üçüncü olarak güvenceli-güvencesiz faiz paritesi ve etkin piyasa hipotezine yönelik literatür taramasına yer verilecektir. Dördüncü olarak ekonometrik analiz için gerekli veri seti ve metodoloji tanıtılacak ve elde edilen uygulama sonuçları açıklanacaktır. Son olarak ise faiz paritesi ve piyasa etkinliği hipotezinin çalışmaya dahil edilen ülkeler için geçerliliğinin açıklanacağı sonuç ve değerlendirme kısmına yer verilecektir.

\section{Faiz Oranı Paritesi Teorisi}

Faiz oranı paritesi, farklı piyasalarda yer alan finansal varlıkların getirileri arasındaki ilişkiyi açıklayan önemli bir yaklaşımdır (Melvin ve Norrbin, 2013: 115). En genel ifadeyle, uluslararası finansal piyasalar arasında farklı para birimi ile fiyatlandırımış benzer menkul varlıkların aynı getiriye sahip olması gerekliliğini ifade eder (Krugman ve Obstfeld, 2009: 336). Temel olarak iki kısımda incelenmektedir: Güvenceli ve güvencesiz faiz paritesi.

\subsection{Güvenceli Faiz Paritesi}

Güvenceli faiz paritesi, döviz kurlarında meydana gelebilecek ani şokların beklenmedik kayıplara yol açmaması için, gelecekte elde edilmesi beklenen döviz kazançlarının vadeli döviz sözleşmesi vasıtasıyla cari dönem itibariyle satılması işlemidir. Güvenceli faiz paritesi yatırımcıları bir yandan döviz kuru riskinin yaratacağı kayıplara karşı korumaktayken, diğer yandan faiz farklılıklarından kaynaklanan avantajı elde etmek için faydalı bir yol sağlamaktadır (Gerber, 2014: 219-220).

Vadeli döviz sözleşmeleri, yatırımcıların vadeli döviz piyasalarında başvurdukları bir uygulamadır. Bu sözleşmeler, belirlenen vadede yabancı paranın yerli paraya dönüştürüleceği döviz kurunu açık bir şekilde gösteren ve işlemlerin yürütüldüğü dönemdeki döviz kurları (spot kur) ile aynı olmayan geleceğe yönelik anlaşmaları kapsamaktadır (Copeland, 2005: 90).

Güvenceli faiz paritesine göre, riskten kaçınan bir yatırımcının finansal piyasa yatırımlarına yönelik olarak iki alternatifinin bulunduğu söylenebilir (Melvin ve Norrbin, 2013: 115; Gandolfo, 2002: 43):

(i) Yatırımlarını yurtiçi faiz oranı ile değerlendiren yatırımcılar, belirlenen vade sonunda yatırılan her bir yerli para birimi için $(1+R)$ gelir elde edeceklerdir.

(ii) Yatırımlarını yurtdışı faiz oranı ile değerlendirmek isteyen yatırımcılar ise döviz kuru riskini göz önünde bulunduracaktır. Bir birim yerli para birimi karşılığında (1/S) birim döviz elde 
edecek yatırımcı, belirlenen vade sonunda $\left(1+R^{*}\right)(1 / S)$ miktar yabancı gelir elde edecektir. Bununla birlikte döviz kurunun gelecek değerinin kesin olarak bilinmemesi nedeniyle oluşacak döviz kuru belirsizliğini ortadan kaldırmak için vadeli sözleşmelerin kullanılması durumunda vade sonunda $\left(1+R^{*}\right)(F / S)$ miktar yerli para elde edecektir.

Bu bilgilerden hareketle aşağıda yer alan eşitliğin sağlanması durumunda yatırımcılar yerli ve yabancı piyasalar arasında farksız olacaktır:

$$
(1+\mathrm{R})=\frac{\mathrm{F}}{\mathrm{S}}\left(1+\mathrm{R}^{*}\right)
$$

$R$ yurtiçi piyasadaki faiz oranını, $R^{*}$ yurtdışı piyasadaki faiz oranını, $F$ vadeli döviz kuru ve $S$ spot döviz kuru göstermektedir. Eşitliğin sağlanmış olması piyasalar arasında hiçbir arbitraj fırsatının bulunmadığını işaret etmektedir (Sarno ve Taylor, 2002: 6). Ancak piyasalar arasında yaşanacak farklılaşma yatırımcılara kar fırsatı sağlayarak, yatırım kararlarının değişmesine neden olabilmektedir. Vadeli kurun, spot kurdan daha yüksek olması (yani F $>$ S), yerli para biriminin değer kaybedeceği beklentisine ve iskontolu satılacağına işaret edecektir. Aksine vadeli kurun spot kurdan düşük olması (yani $\mathrm{F}<\mathrm{S}$ ) ise, yerli para biriminin değer kazanacağı ve primli satılacağını ifade etmektedir (Gerber, 2014: 220).

$$
\begin{aligned}
& \text { 1. koşul: }(1+R)>\frac{F}{S}\left(1+R^{*}\right) \\
& \text { 2. koşul: }(1+R)<\frac{F}{S}\left(1+R^{*}\right)
\end{aligned}
$$

Buna göre yatırımcı, 1. koşulda sermayesini yurtiçi faiz oranına, 2. koşulda ise sermayesini yurtdışı faiz oranına yönelik menkul varlıklara yatırmayı tercih edecektir (Levi, 2009: 114; Husted ve Melvin, 2013, s. 256).

Güvenceli faiz paritesi bir diğer şekilde aşağıdaki eşitlik yardımıyla gösterilebilmektedir²:

$$
\mathrm{R}-\mathrm{R}^{*}=\frac{\mathrm{F}-\mathrm{S}}{\mathrm{S}} \quad \text { veya } \quad \mathrm{R}=\mathrm{R}^{*}+\frac{\mathrm{F}-\mathrm{S}}{\mathrm{S}}
$$

Bu eşitlik, faiz oranı farklıııklarının vadeli kur marjına (prim/iskonto) eşit olduğu veya yurtiçi faiz oranının, yurtdışı faiz oranı ve vadeli kur marjının toplamına eşit olduğunu ifade etmektedir (Gandolfo, 2002: 45).

\subsection{Güvencesiz Faiz Paritesi}

Güvencesiz faiz paritesi, yurtiçi ve yurtdışı faiz oranları arasındaki bir farkın, döviz kurunun gelecek değerindeki "beklenen" değişime eşit olması gerektiğini ifade etmektedir. Bunun anlamı cari spot kurun, gelecekte beklenen döviz kuru ile yurtiçi ve yurtdışı faiz oranlarına bağlı olmasıdır. Bu üç değişkenin herhangi birinde yaşanacak beklenmedik bir değişim, spot kurun yeniden düzenlenmesini beraberinde getirecektir (Visser, 2004: 10-12).

Güvencesiz faiz paritesinde vadeli döviz sözleşmelerinin kullanılması söz konusu değildir. Temelinde yabancı para birimine dayalı varlıklardan elde edilecek gelirlerin, gelecek bir tarihte "beklenen spot döviz kurunun" kullanılması ile yerli para birimine dönüştürülmesi düşüncesi yer

${ }^{2}(1+R)=\frac{F}{S}\left(1+R^{*}\right)$ eşitliğinin her iki tarafı $\left(1+R^{*}\right)$ ile bölünür ve 1 çıkarılırsa $\frac{\left(R-R^{*}\right)}{\left(1+R^{*}\right)}=\frac{F-S}{S}$ eşitliği elde edilir. Bu eşitlik "mutlak faiz oranı paritesi" koşulu olarak bilinmektedir. Eşitliğin sol tarafında yer alan ifadenin paydasının daima 1'e eşit olduğu hesaba katıldığında "güvenceli faiz oranı paritesi" koşulu elde edilmektedir (Melvin ve Norrbin, 2013: 115). 
almaktadır. Ancak gelecekte beklenen spot kurun tam olarak bilinmemesi, yatırımcıları döviz kuru riski ile karşı karşıya bırakabilmektedir (Pugel, 2016: 417).

Yatırımcılar, döviz kurlarının gelecekte izleyeceği yollar ile ilgili tam bir bilgiye sahip olmamaları veya belirsizlik durumunda, riske karşı duyarsız (risk neutral) olacaklardır. Bunun anlamı sermaye sahiplerinin sadece yatırımlarının beklenen getirisi ile ilgilendikleri, buna karşın risk ile ilgilenmedikleridir (McDonald, 2007: 17).

Güvenceli faiz paritesinde olduğu gibi güvencesiz faiz paritesinde de yatırımcıların finansal piyasa yatırımlarına yönelik olarak iki alternatifinin bulunduğu söylenebilir (Copeland, 2005: 8586):

(i) Yatırımlarını yurtiçi faiz oranı ile değerlendiren yatırımcılar, belirlenen vade sonunda yatırılan her bir yerli para birimi için $(1+R)$ gelir elde edeceklerdir.

(ii) Yatırımlarını yurtdışı faiz oranı ile değerlendirmek isteyen yatırımcılar ise bir birim yerli para birimi karşılığında (1/S) birim döviz ve belirlenen vade sonunda $\left(1+R^{*}\right)(1 / S)$ miktar yabancı gelir elde edeceklerdir. Vade sonunda döviz gelirlerini ulusal para birimine dönüştürdüğünde, mevcut dönemdeki döviz kurundan hareket edecek ve yatırım öncesinde planladığı beklenen döviz kuru ile $\left(1+R^{*}\right)\left(S^{E} / S\right)$ miktar yerli para elde edecektir.

Bu bilgilerden hareketle, aşağıda yer alan eşitliğin sağlanması durumunda yatırımcılar sermayesini yurtiçi veya yurtdışı piyasalar arasında kullanma anlamında farksız olacaklardır (Gandolfo, 2002: 46):

$$
(1+R)=\frac{S^{E}}{S}\left(1+R^{*}\right)
$$

$R$ yurtiçi faiz oranı, $R^{*}$ yurtdışı faiz oranı, $S$ spot kur ve $S^{E}$ beklenen döviz kuru ifade etmektedir. Güvencesiz faiz paritesi bir diğer şekilde aşağıdaki eşitlik yardımıyla gösterilebilmektedir ${ }^{3}$ :

$$
\mathrm{R}-\mathrm{R}^{*}=\frac{\mathrm{S}^{\mathrm{E}}-\mathrm{S}}{\mathrm{S}} \text { veya } \mathrm{R}=\mathrm{R}^{*}+\frac{\mathrm{S}^{\mathrm{E}}-\mathrm{S}}{\mathrm{S}}
$$

Bu eşitlik, beklentiler sabitken, yurtiçi faiz oranında bir artış yaşanması durumunda, döviz kurunun beklenen değerinde bir azalma eğiliminin gerçekleşeceğini ifade etmektedir. Bu durumda ulusal para değer kazanırken yabancı para değer kaybedecektir. Diğer taraftan, güvencesiz faiz paritesi, yatırımcıların, nispeten daha düşük (yüksek) faiz oranına sahip ülkelerin para biriminin değerinde artış (azalma) yaşanacağı beklentisine sahip olduklarını ifade etmektedir (Husted ve Melvin, 2013: 292).

\section{Güvencesiz Faiz Paritesi ve Risk Primi}

Güvencesiz faiz paritesi, deterministik beklentiler ve yatırımcıların riske karşı duyarsızlığı olmak üzere iki güçlü varsayıma dayanmaktadır. Ancak piyasalarda çoğunlukla döviz kurunun gelecek değeri hakkında bir belirsizlik ve riskten kaçınan yatırımcı profilleri bulunmaktadır. Bu durum bir risk katsayısının veya "risk priminin" hesaba katılması gerekliliğini karşımıza çıkarmaktadır (Gandolfo, 2002: 47).

${ }^{3}(1+R)=\frac{S^{E}}{S}\left(1+R^{*}\right)$ eşitliğinin her iki tarafı $\left(1+i_{F}\right)$ ile bölünür ve 1 çıkarılsa $\frac{R-R^{*}}{1+R^{*}}=\frac{S^{E}-S}{S} \quad$ eşitliği elde edilir. Eşitliğin sol tarafında yer alan ifadenin paydasının daima 1'e eşit olduğu hesaba katıldığında "güvencesiz faiz oranı paritesi" koşulu elde edilmektedir (Gandolfo, 2002: 46). 
Risk primi, genel olarak, yerli yatırımcıların yabancı menkul varlık sahibi olmaları durumunda karşılaşacakları ilave riski tanzim etmek için göz önünde bulundurdukları önemli bir katsayı olarak ifade edilebilir. Illave risk, güvencesiz faiz paritesine risk priminin dâhil edilmesiyle giderilebilir (Salvatore, 2013: 483).

$$
R=R^{*}+\frac{S^{E}-S}{S}+R P
$$

Burada RP, risk katsayısı veya risk primidir ve denklemde yer alan diğer değiş̧kenler gibi oransal olarak ifade edilmektedir (Gandolfo, 2002: 47). Güvencesiz faiz paritesi, yerli ve yabancı varlıkların tam ikame edilebilirliği varsayımında geçerli olmaktadır. Bu durumda döviz piyasasındaki denge, yurtiçi faiz oranının, yabancı varlıkların yerli para birimi cinsinden beklenen kazançları ile risk priminin toplamına eşit olması ile gerçekleşecektir (Krugman ve Obstfeld, 2009: 479).

Risk primi, farklı para birimlerine bağlı varlıklar üzerindeki beklenen getiriler arasındaki farkIılık veya gelecekte beklenen spot kur ve cari vadeli kur arasındaki farklılık ile ölçülebilir. Risk priminin sıfıra eşit olması, yurtiçi ve yurtdışı varlıklar arasındaki beklenen kazançların eşit olduğunu ifade etmektedir. Ancak risk priminin pozitif bir değer alıyor olması, yurtdışı varlıkların daha az cazibeye sahip olduğunu göstermektedir (Visser, 2004: 28-30).

Risk primli güvencesiz faiz paritesi modeli, kısa dönem döviz kuru hareketlerine temel bir teorik model sağlamaktadır. Modelin kendisi mantıksal olarak tutarlıdır ve modelin temel tahminleri genel olarak gerçeklikle uyumludur. Fakat istatistiki testler bu modelin dışında reel dünyada döviz kuru davranışlarını etkileyen çok daha fazla faktörün olduğunu göstermektedir (Husted ve Melvin, 2013: 296).

\section{Faiz Paritesinden Sapmaların Nedenleri}

Faiz oranı paritesi, uluslararası finansal piyasalarda işlem gören menkul kıymetler için kesin bir mekanizmayı ifade etmektedir. Ancak faiz paritesinin geçerliliğini engelleyebilecek bazı faktörler bulunmaktadır: (i) Döviz kurlarının gelecekte oluşacak değerinin cari dönem itibariyle bilinememesi durumunu ifade eden döviz kuru riski. (ii) Finansal varlıkların alım satımı arasında meydana gelebilecek işlem maliyetlerinin varlığı. (iii) Ülkeler arasında uygulanan vergi politikalarındaki farklılıklar. (iv) Hükümetlerin sermaye hareketleri üzerinde yapmayı planladıkları düzenlemeleri ifade eden hükümet kontrolleri. (v) Ülkelerin rejimlerinde yaşanabilecek değişikliklerin ortaya çıkarabileceği politik risk. (vi) Yerli ve yabancı menkul varlıklar arasındaki likidite farklılıkları. (vii) Teknik aksaklıklar nedeniyle faiz oranı ve döviz kuru verilerinin aynı zaman aralığında derlenememesi sonucu oluşabilecek yanıltıcı kar veya zarar arbitraj olanakları (Pugel, 2016: 405-406; Melvin ve Norrbin, 2013: 118-119; Levi, 2009: 134-139; Dunn ve Mutti, 2000: 356).

\section{Etkin Piyasa Hipotezi}

Etkin piyasa hipotezi 1970'li yılların başlarında Eugene Fama tarafından literatüre kazandırılan bir yaklaşımdır (Kallianiotis, 2013: 98). En genel ifadeyle, fiyatların piyasada yer alan mevcut bilgileri daima tam olarak yansıttığı fikrine dayanmaktadır. Buna göre ideal bir piyasada firmalar üretim-yatırım kararları verebilmekte ve yatırımcılar ise firmaların faaliyetlerini temsil eden varIıklar arasında etkin bir seçim yapabilmektedir (Fama, 1970: 383).

Etkin bir spekülatif piyasada, fiyatların piyasa katılımcılarına mevcut bilgileri tamamen yansıtması, yatırımcılar için spekülasyon vasıtasıyla aşırı kar elde edebilme imkanını ortadan kaldır- 
maktadır. İki temel varsayıma dayanmaktadır: (i) Döviz piyasası katılımcıları rasyonel beklentilere sahiptir. (ii) Döviz piyasası katılımcıları riske karşı duyarsızdır. Bu hipotez ayrıca risk kavramını kapsamına alarak genişletilebilir. Böyle bir durumda etkin piyasa hipotezi, bir denge kazanç ve rasyonel beklentiler modeli halini almaktadır (Sarno ve Taylor, 2002: 5).

Etkin piyasa yaklaşımı, döviz piyasasında spot ve vadeli döviz kurların yeni bilgiler karşısında hızlı bir şekilde uyarlanabildiğini ifade etmektedir. Buna göre vadeli döviz kuru gelecekte beklenen spot kurdan sadece risk primi kadar farklılaşmaktadır. Ancak piyasaların etkin olmaması durumunda fiyatlar yeni bilgiye hızlı bir şekilde uyarlanamamakta ve bilgi sahibi olan yatırımcılar için döviz kuru ticaretinden kar elde etme fırsatı ortaya çıkmaktadır (Melvin ve Norrbin, 2013: 159).

Etkin bir döviz piyasasında güvenceli ve güvencesiz faiz pariteleri geçerlidir (Gandolfo, 2002: 48). Buradan hareketle etkin piyasa hipotezi aşağıdaki eşitlik ile ifade edilebilir:

$$
\frac{F-S}{S}=\frac{S^{E}-S}{S} \text { ise } F=S^{E} \text { dir. }
$$

Buna göre, karar birimlerinin rasyonel beklentilere sahip olduğu ve risk priminin bulunmadığı etkin bir piyasada vadeli döviz kuru, gelecekte beklenen spot kurun en iyi belirleyicisi durumundadır. Risk priminin bulunması durumunda ise aşağıdaki eşitlik doğru bir tahminci durumundadır:

$$
F=S^{E}+R P
$$

Buna göre vadeli kur, risk priminin varlığı nedeniyle, sistematik olarak gelecekte beklenen spot kurun altında veya üzerinde tahmin edilebilmektedir. Yabancı para birimi üzerinde pozitif (negatif) bir risk priminin bulunması durumunda, yerli para biriminin bir dönem önceki vadeli kuru, bir dönem önceki fiili kura kıyasla, aşırı (eksik) değerli bir yapıya sahip olacaktır (Pilbeam, 2005: 205).

\section{Piyasa Etkinliğinin Derecesi}

Etkin piyasa görüşü, varlık fiyatlarının uyarlanması ile ilgili olarak üç farklı bilgi seti altında ele alınmaktadır: (i) Zayıf Etkinlik, (ii) Yarı-Güçlü Etkinlik ve (iii) Güçlü Etkinlik (Fama, 1970, s. 383). Zayıf etkinlik, belirli bir varlık üzerinde sadece tarihsel fiyatların ve getirilerin bilgi setine dâhil edilmesi durumunu ifade etmektedir. Bunun anlamı mevcut varlık fiyatlarının, menkul varı̆̆ın geçmiş fiyatları ile ilgili her şeyi yansıttığıdır. Yarı güçlü etkinlik, fiyatların bilgi seti içerisine kamusal anlamda bilinen bütün bilgileri (yıllık kazanç duyuruları, hisse bölünmeleri vb.) dâhil etmesi durumunda ortaya çıkmaktadır. Güçlü etkinlik ise herhangi bir yatırımcı veya grubun (yatırım fonları yönetimi vb.) fiyatların oluşumu ile ilgili herhangi bir bilgiye yönelik tekelci erişimlerinin bulunup bulunmadığını bilgi setine dâhil etmektedir (Levi, 2009: 363; Fama, 1970: 388).

\section{Literatür Taraması}

Faiz oranı paritesi literatürde oldukça yoğun bir çalışma alanına sahip olmasına karşın, piyasa etkinliğine yönelik çalışmaların nispeten daha az olduğu söylenebilir. Faiz oranı paritesi ve etkin piyasa hipotezine yönelik literatürde yer alan çalışmalardan bazıları sırasıyla Tablo 1 ve Tablo 2'de yer almaktadır. 
Tablo 1: Faiz Oranı Paritesi İçin Seçili Literatür

\begin{tabular}{|c|c|c|c|c|}
\hline Yazar(lar) & Dönem(ler) & Ülke(ler) & Yöntem(ler) & Sonuç \\
\hline Sharpe (1984) & $\begin{array}{c}\text { 1978-1982 } \\
\text { haftalık veriler }\end{array}$ & Avustralya & $\begin{array}{l}\text { Çok Değişkenli } \\
\text { ARIMA } \\
\text { Modelleri }\end{array}$ & $\begin{array}{l}\text { Güvenceli faiz paritesi } \\
\text { geçerlidir. }\end{array}$ \\
\hline $\begin{array}{l}\text { Committeri vd. } \\
\text { (1993) }\end{array}$ & $\begin{array}{l}26 \text { Ocak-24 Şubat } \\
1989 \text { günlük veriler }\end{array}$ & $\begin{array}{c}\text { İtalya, Almanya ve } \\
\text { ABD }\end{array}$ & - & $\begin{array}{l}\text { Güvenceli faiz paritesi } \\
\text { geçerlidir. }\end{array}$ \\
\hline Moosa (1996b) & $\begin{array}{l}\text { 1985:M1-1994:M12 } \\
\text { aylık veriler }\end{array}$ & $\begin{array}{c}\text { Avustralya ve Yeni } \\
\text { Zelanda }\end{array}$ & $\begin{array}{l}\text { Eşbütünleşme Ana- } \\
\text { lizi }\end{array}$ & $\begin{array}{l}\text { Güvenceli faiz paritesi } \\
\text { geçerli değildir. }\end{array}$ \\
\hline $\begin{array}{l}\text { Balke ve Wohar } \\
\text { (1998) }\end{array}$ & $\begin{array}{l}\text { 1974:1-1993:9 gün- } \\
\text { lük veriler }\end{array}$ & İngiltere ve $A B D$ & $\begin{array}{l}\text { EKK ve ARCH Tah- } \\
\text { mini }\end{array}$ & $\begin{array}{l}\text { Güvenceli faiz paritesi } \\
\text { geçerli değildir. }\end{array}$ \\
\hline $\begin{array}{l}\text { Bansal ve } \\
\text { Dahquist (2000) }\end{array}$ & $\begin{array}{l}\text { 1976:1-1998:5 haf- } \\
\quad \text { talık veriler }\end{array}$ & $\begin{array}{c}16 \text { Gelişmiş ve } 12 \\
\text { Gelişen Piyasa Eko- } \\
\text { nomisi }\end{array}$ & $\begin{array}{l}\text { Havuzlanmış Yatay } \\
\text { Kesit Metodu }\end{array}$ & $\begin{array}{l}\text { Vadeli prim paradoksu } \\
\text { gelişmiş ülkeler için } \\
\text { geçerlidir. }\end{array}$ \\
\hline $\begin{array}{l}\text { Sachsida } \\
\text { vd.(2001) }\end{array}$ & $\begin{array}{l}\text { 1984:M1-1998:M10 } \\
\text { aylık veriler }\end{array}$ & Brezilya & EKK Tahmini & $\begin{array}{l}\text { Güvencesiz faiz pari- } \\
\text { tesi esnek döviz kuru } \\
\text { sistemi dönemleri için } \\
\text { geçerlidir. }\end{array}$ \\
\hline $\begin{array}{l}\text { Francis vd. } \\
(2002)\end{array}$ & $\begin{array}{l}\text { 1980-2000 aylık ve- } \\
\text { riler }\end{array}$ & $\begin{array}{l}9 \text { Gelişen Piyasa } \\
\text { Ekonomisi }\end{array}$ & GARCH & $\begin{array}{l}\text { Güvencesiz faiz pari- } \\
\text { tesi geçerli değildir. }\end{array}$ \\
\hline $\begin{array}{l}\text { Lee ve } \mathrm{Wu} \\
(2004)\end{array}$ & $\begin{array}{l}\text { 1988:M1-1997:M6 } \\
\text { aylık veriler }\end{array}$ & $\begin{array}{l}8 \text { Asya } \\
\text { Ekonomisi }\end{array}$ & $\begin{array}{l}\text { Panel Birim Kök } \\
\text { Testleri }\end{array}$ & $\begin{array}{l}\text { Faiz paritesi ABD faiz } \\
\text { oranları dikkate alındı- } \\
\text { ğında geçerlidir. }\end{array}$ \\
\hline Goh vd. (2006) & $\begin{array}{l}\text { 1978:M1-2002:M2 } \\
\text { aylık veriler }\end{array}$ & Malezya & SWARCH & $\begin{array}{c}\text { Rejim değişiklikleri, gü- } \\
\text { vencesiz faiz paritesin- } \\
\text { deki sapmaları azalt- } \\
\text { maktadır. }\end{array}$ \\
\hline $\begin{array}{l}\text { Adrangi vd. } \\
\text { (2007) }\end{array}$ & $\begin{array}{l}\text { 1978:M5-1997:M1 } \\
\text { aylık veriler }\end{array}$ & $\begin{array}{l}\text { Kore, Filipinler ve } \\
\text { Tayland }\end{array}$ & $\begin{array}{l}\text { VAR ve } \\
\text { Regresyon } \\
\text { Analizleri }\end{array}$ & $\begin{array}{l}\text { Güvencesiz faiz pari- } \\
\text { tesi geçerli değildir. }\end{array}$ \\
\hline $\begin{array}{l}\text { Erdemlioğlu } \\
(2007)\end{array}$ & $\begin{array}{l}\text { 2001:M12-2007:M6 } \\
\text { aylık veriler }\end{array}$ & Türkiye & $\begin{array}{c}\text { ARCH ve GARCH } \\
\text { Modelleri }\end{array}$ & $\begin{array}{l}\text { Güvencesiz faiz pari- } \\
\text { tesi geçerli değildir. }\end{array}$ \\
\hline $\begin{array}{l}\text { Chin ve Liang } \\
\text { (2009) }\end{array}$ & $\begin{array}{l}\text { 1979:M1-2005:M12 } \\
\text { aylık veriler }\end{array}$ & $\begin{array}{l}A B D, \text { İngiltere ve Al- } \\
\text { manya }\end{array}$ & GMM Tahmini & $\begin{array}{l}\text { Güvencesiz faiz pari- } \\
\text { tesi geçerlidir. }\end{array}$ \\
\hline $\begin{array}{l}\text { Batten ve Szi- } \\
\text { lagyi (2010) }\end{array}$ & $\begin{array}{l}\text { 1983-2005 farklılaş- } \\
\text { mış veriler }\end{array}$ & $A B D$ ve Japonya & $\begin{array}{c}\text { ARCH ve GARCH } \\
\text { Analizi }\end{array}$ & $\begin{array}{l}\text { Güvenceli faiz paritesi } \\
\text { geçerlidir. }\end{array}$ \\
\hline $\begin{array}{l}\text { Mylonidis ve Se- } \\
\text { mertzidou } \\
(2010)\end{array}$ & $\begin{array}{l}\text { 1980:M1-2008:M8 } \\
\text { aylık veriler }\end{array}$ & $\begin{array}{l}\text { ABD, Kanada, Avust- } \\
\text { ralya ve Japonya }\end{array}$ & GMM Tahmini & $\begin{array}{l}\text { Güvencesiz faiz pari- } \\
\text { tesi geçerli değildir. }\end{array}$ \\
\hline $\begin{array}{l}\text { Guender ve } \\
\text { Cook (2011) }\end{array}$ & $\begin{array}{l}\text { 1986:Q1-2008:Q3 } \\
\text { çeyreklik veriler }\end{array}$ & $\begin{array}{c}\text { Avustralya ve Yeni } \\
\text { Zelanda }\end{array}$ & EKK Tahmini & $\begin{array}{l}\text { Güvencesiz faiz pari- } \\
\text { tesi geçerlidir. }\end{array}$ \\
\hline $\begin{array}{l}\text { Kim ve Cho } \\
\text { (2011) }\end{array}$ & $\begin{array}{l}\text { 1994:M1-2008:M6 } \\
\text { aylık veriler }\end{array}$ & $\begin{array}{l}\text { ABD, Japonya, İngil- } \\
\text { tere, Singapur, Kore, } \\
\text { Malezya ve Tayland }\end{array}$ & EKK Tahmini & $\begin{array}{l}\text { Güvencesiz faiz pari- } \\
\text { tesi geçerli değildir. }\end{array}$ \\
\hline
\end{tabular}


Eskişehir Osmangazi Üniversitesi iiBF Dergisi

\begin{tabular}{|c|c|c|c|c|}
\hline Lily vd. (2012) & $\begin{array}{l}\text { 1998:Q1-2010:Q3 } \\
\text { çeyreklik veriler }\end{array}$ & Malezya & ARDL Sınır Testi & $\begin{array}{l}\text { Güvencesiz faiz pari- } \\
\text { tesi geçerli değildir. }\end{array}$ \\
\hline Ozdemir (2013) & $\begin{array}{l}\text { 2000:Q1-2005:Q4 } \\
\text { çeyreklik veriler }\end{array}$ & $\begin{array}{l}\text { Gelişmiş ve Geliş- } \\
\text { mekte Olan } 30 \text { Ülke }\end{array}$ & $\begin{array}{l}\text { Panel Veri } \\
\text { Analizi }\end{array}$ & $\begin{array}{l}\text { Güvencesiz faiz pari- } \\
\text { tesi geçerli değildir. }\end{array}$ \\
\hline Bhatti (2014) & $\begin{array}{l}\text { 1994:Q1-2010:Q2 } \\
\text { çeyreklik veriler }\end{array}$ & $\begin{array}{l}\text { Ermenistan, Azer- } \\
\text { baycan, Gürcistan, } \\
\text { Kazakistan, Kırgızis- } \\
\text { tan ve Moldova }\end{array}$ & $\begin{array}{l}\text { Birim Kök, EKK ve } \\
\text { Eşbütünleşme Ana- } \\
\text { lizleri }\end{array}$ & $\begin{array}{l}\text { Güvencesiz faiz pari- } \\
\text { tesi geçerlidir. }\end{array}$ \\
\hline $\begin{array}{l}\text { Omer, Haan ve } \\
\text { Scholtens (2014) }\end{array}$ & $\begin{array}{l}1 \text { Ocak 2001-31 Ara- } \\
\text { lık } 2008 \text { günlük veri- } \\
\text { ler }\end{array}$ & 7 Ülke & $\begin{array}{l}\text { Panel Birim Kök ve } \\
\text { Eşbütünleşme Ana- } \\
\text { lizi }\end{array}$ & $\begin{array}{l}\text { Güvencesiz faiz pari- } \\
\text { tesi geçerlidir. }\end{array}$ \\
\hline $\begin{array}{l}\text { Chang ve Su } \\
(2015)\end{array}$ & $\begin{array}{l}\text { 1998:M1-2012:M12 } \\
\text { aylık veriler }\end{array}$ & $\begin{array}{l}\text { Hong Kong, Endo- } \\
\text { nezya, Japonya, } \\
\text { Kore ve Singapur }\end{array}$ & $\begin{array}{l}\text { Doğrusal Olmayan } \\
\text { Birim Kök Testleri }\end{array}$ & $\begin{array}{l}\text { Güvencesiz faiz pari- } \\
\text { tesi geçerlidir. }\end{array}$ \\
\hline Fukuda (2016) & $\begin{array}{l}\text { 2007-2009 günlük } \\
\text { veriler }\end{array}$ & ABD ve Japonya & GARCH Testi & $\begin{array}{l}\text { Güvenceli faiz paritesi } \\
\text { geçerli değildir. }\end{array}$ \\
\hline Lothian (2016) & $\begin{array}{c}\text { Veri aralığı ülkelere } \\
\text { göre 92-217 yıl ara- } \\
\text { sında değişmekte- } \\
\text { dir. }\end{array}$ & 17 Ülke & $\begin{array}{l}\text { Regresyon } \\
\text { Analizi }\end{array}$ & $\begin{array}{l}\text { Güvencesiz faiz pari- } \\
\text { tesi geçerlidir. }\end{array}$ \\
\hline
\end{tabular}

Tablo 2: Etkin Piyasa Hipotezi Için Seçili Ampirik Literatür

\begin{tabular}{|c|c|c|c|c|}
\hline Yazar(lar) & Dönem(ler) & Ülke(ler) & Yöntem & Sonuç \\
\hline $\begin{array}{l}\text { Hakkio ve Rush } \\
\text { (1989) }\end{array}$ & $\begin{array}{c}\text { 1975:M7-1986:M10 } \\
\text { aylık veriler }\end{array}$ & $\begin{array}{l}\text { Almanya ve } \\
\text { Ingiltere }\end{array}$ & $\begin{array}{l}\text { Eşbütünleşme Ana- } \\
\text { lizi }\end{array}$ & $\begin{array}{l}\text { Piyasa etkinliği hipo- } \\
\text { tezi geçerli değildir. }\end{array}$ \\
\hline Lai ve Lai (1991) & $\begin{array}{c}\text { 1973:M7-1989:M12 } \\
\text { aylık veriler }\end{array}$ & $\begin{array}{c}\text { İngiltere, } \\
\text { Almanya, İsveç Kanada } \\
\text { ve } \\
\text { Japonya }\end{array}$ & $\begin{array}{l}\text { Birim Kök ve Eşbü- } \\
\text { tünleşme Analizi }\end{array}$ & $\begin{array}{l}\text { Piyasa etkinliği hipo- } \\
\text { tezi geçerli değildir. }\end{array}$ \\
\hline $\begin{array}{l}\text { Karfakis ve Pa- } \\
\text { rikh (1994) }\end{array}$ & $\begin{array}{c}\text { 1975:M1-1990:M2 } \\
\text { aylık veriler }\end{array}$ & $\begin{array}{l}\text { Avustralya, ABD Ja- } \\
\text { ponya, İngiltere, Al- } \\
\text { manya ve } \\
\text { Fransa }\end{array}$ & $\begin{array}{l}\text { Eşbütünleşme Ana- } \\
\text { lizi }\end{array}$ & $\begin{array}{c}\text { Piyasa etkinliği hipo- } \\
\text { tezi } \\
\text { geçerlidir. }\end{array}$ \\
\hline Ukpolo (1995) & $\begin{array}{c}\text { 1983:M1-1992:M12 } \\
\text { aylık veriler }\end{array}$ & Japonya & $\begin{array}{l}\text { Eşbütünleşme Ana- } \\
\text { lizi }\end{array}$ & $\begin{array}{l}\text { Piyasa etkinliği hipo- } \\
\text { tezi geçerli değildir. }\end{array}$ \\
\hline $\begin{array}{l}\text { Wu ve Chen } \\
(1998)\end{array}$ & $\begin{array}{l}\text { 1979:1-1995:12 } \\
\text { günlük spot kur ve } \\
\text { 30, } 60 \text { ve } 90 \text { günlük } \\
\text { forward kur verileri }\end{array}$ & 9 OECD Ülkesi & $\begin{array}{c}\text { Panel Birim Kök } \\
\text { Testleri }\end{array}$ & $\begin{array}{c}\text { Piyasa etkinliği hipo- } \\
\text { tezi } \\
\text { geçerlidir. }\end{array}$ \\
\hline $\begin{array}{l}\text { Choudhry } \\
\text { (1999) }\end{array}$ & $\begin{array}{c}\text { 1985:M1-1996:M12 } \\
\text { aylık veriler }\end{array}$ & $\begin{array}{l}\text { Avustralya, Kanada, } \\
\text { Fransa, Almanya, } \\
\text { Hong Kong, İtalya, Ja- } \\
\text { ponya, Güney Afrika } \\
\text { ve İngiltere }\end{array}$ & $\begin{array}{l}\text { Eşbütünleşme Ana- } \\
\text { lizi }\end{array}$ & $\begin{array}{l}\text { Piyasa etkinliği hipo- } \\
\text { tezi genel olarak ge- } \\
\text { çerli değildir. }\end{array}$ \\
\hline
\end{tabular}




\begin{tabular}{|c|c|c|c|c|}
\hline $\begin{array}{l}\text { Dutt ve Ghosh } \\
\text { (1999) }\end{array}$ & $\begin{array}{l}\text { 1980:M1-1989:M12 } \\
\text { aylık veriler }\end{array}$ & $\begin{array}{c}\text { İngiltere, Japonya ve } \\
\text { Almanya }\end{array}$ & FMOLS Analizi & $\begin{array}{l}\text { Piyasa etkinliği po- } \\
\text { und ve yen için güçlü } \\
\text { formda geçerlidir. }\end{array}$ \\
\hline $\begin{array}{l}\text { Barkoulas vd. } \\
(2000)\end{array}$ & $\begin{array}{l}\text { 1980:1-1998:12 dö- } \\
\text { nemleri için günlük } \\
\text { veriler }\end{array}$ & $\begin{array}{c}\text { Kanada, İngiltere, Al- } \\
\text { manya, Fransa, İtalya } \\
\text { ve Japonya }\end{array}$ & $\begin{array}{c}\text { Panel Birim Kök ve } \\
\text { Panel Eşbütünleşme } \\
\text { Analizi }\end{array}$ & $\begin{array}{c}\text { Piyasa etkinliği hipo- } \\
\text { tezi } \\
\text { geçerlidir. }\end{array}$ \\
\hline $\begin{array}{l}\text { Jeon ve Lee } \\
\text { (2002) }\end{array}$ & $\begin{array}{l}\text { 1973:6-1996:7 haf- } \\
\text { talık veriler }\end{array}$ & $\begin{array}{c}\text { Kanada, İngiltere Al- } \\
\text { manya, Fransa, Ja- } \\
\text { ponya, İtalya ve İsveç }\end{array}$ & $\begin{array}{l}\text { Eşbütünleşme Ana- } \\
\text { lizi }\end{array}$ & $\begin{array}{c}\text { Piyasa etkinliği hipo- } \\
\text { tezi } \\
\text { geçerlidir. }\end{array}$ \\
\hline $\begin{array}{l}\text { Aroskar vd. } \\
\text { (2004) }\end{array}$ & $\begin{array}{l}\text { 1990:1-1999:12 } \\
\text { günlük veriler }\end{array}$ & $\begin{array}{l}\text { İngiltere, İtalya, Al- } \\
\text { manya ve } \\
\text { Fransa }\end{array}$ & $\begin{array}{l}\text { Eşbütünleşme Ana- } \\
\text { lizi }\end{array}$ & $\begin{array}{l}\text { Piyasa etkinliği hipo- } \\
\text { tezi geçerli değildir. }\end{array}$ \\
\hline Lobell (2004) & $\begin{array}{c}1843-1880 \text { yılları } \\
\text { arasında haftada iki } \\
\text { kez yayınlanan veri- } \\
\text { ler }\end{array}$ & İsveç & ARIMA Yöntemi & $\begin{array}{c}\text { Piyasa etkinliği hipo- } \\
\text { tezi } \\
\text { geçerlidir. }\end{array}$ \\
\hline Ozdemir (2008) & $\begin{array}{l}\text { 1990:1-2005:6 haf- } \\
\text { talık veriler }\end{array}$ & Türkiye & $\begin{array}{c}\text { Birim Kök Testi ve } \\
\text { Varyans Ayrıştırma } \\
\text { Testleri } \\
\end{array}$ & $\begin{array}{l}\text { Piyasa etkinliği hipo- } \\
\text { tezi zayıf formda } \\
\text { geçerlidir. }\end{array}$ \\
\hline Lin vd. (2010) & $\begin{array}{c}3 \text { Ocak 2005-13 } \\
\text { Temmuz } 2006 \text { dö- } \\
\text { nemleri arasında } 15 \\
\text { dakikalık spot kur } \\
\text { verileri } \\
\end{array}$ & Tayvan & $\begin{array}{c}\text { PARCH ve EGARCH } \\
\text { Analizi }\end{array}$ & $\begin{array}{l}\text { Piyasa etkinliği hipo- } \\
\text { tezi yarı güçlü } \\
\text { formda geçerlidir. }\end{array}$ \\
\hline $\begin{array}{l}\text { Ibrahim vd. } \\
\text { (2011) }\end{array}$ & $\begin{array}{l}\text { 2000-2007 } \\
\text { dönemleri için haf- } \\
\text { talık veriler }\end{array}$ & 30 OECD Ülkesi & Birim Kök Testleri & $\begin{array}{l}\text { Piyasa etkinliği hipo- } \\
\text { tezi zayıf formda } \\
\text { geçerlidir. }\end{array}$ \\
\hline $\begin{array}{l}\text { Ahmad vd. } \\
\text { (2012) }\end{array}$ & $\begin{array}{l}\text { 1997:1-2010:6 gün- } \\
\text { lük veriler }\end{array}$ & 12 Asya-Pasifik Ülkesi & $\begin{array}{l}\text { Eşbütünleşme Ana- } \\
\text { lizi }\end{array}$ & $\begin{array}{l}\text { Piyasa etkinliği hipo- } \\
\text { tezi genel olarak ge- } \\
\text { çerli değildir. }\end{array}$ \\
\hline Çiçek (2014) & $\begin{array}{l}\text { 2005:2-2013:7 gün- } \\
\text { lük veriler }\end{array}$ & Türkiye & $\begin{array}{l}\text { Birim Kök ve Eşbü- } \\
\text { tünleşme Analizleri }\end{array}$ & $\begin{array}{l}\text { Döviz piyasası zayıf } \\
\text { formda etkin, yarı } \\
\text { güçlü formda etkin } \\
\text { değildir. }\end{array}$ \\
\hline $\begin{array}{l}\text { Markovsky } \\
\text { (2014) }\end{array}$ & $\begin{array}{l}\text { 2001:M2-2013:M1 } \\
\text { aylık veriler }\end{array}$ & $\begin{array}{l}\text { Orta Avrupa } \\
\text { Ülkeleri }\end{array}$ & $\begin{array}{c}\text { Panel Eşbütünleşme } \\
\text { Analizi }\end{array}$ & $\begin{array}{c}\text { Piyasa etkinliği hipo- } \\
\text { tezi } \\
\text { geçerlidir. }\end{array}$ \\
\hline
\end{tabular}

\section{Ekonometrik Yöntem}

Faiz Oranı Paritesi İçin Test Yöntemleri: Faiz oranı paritesi güvenceli, güvencesiz ve reel faiz paritesi olmak üzere üç farklı formda analiz edilebilmektedir. Bu çalışmada faiz oranı paritesi güvencesiz versiyonuyla test edilecektir. Güvencesiz faiz oranı paritesi modeli aşağıda yer alan eşitlik yardımıyla gösterilebilir (Bhatti, 2014, s. 234; Carvalho vd., 2004, s. 265; Tang, 2011, s. 569):

$$
\begin{array}{cc} 
& s_{\mathrm{t}+1}-\mathrm{s}_{\mathrm{t}}=\beta_{0}+\beta_{1}\left(r-\mathrm{r}^{*}\right)_{\mathrm{t}}+\mathrm{u}_{\mathrm{t}+1} \\
\mathrm{~s}_{\mathrm{t}} & : \text { t dönemindeki cari spot kurun logaritması } \\
\mathrm{s}_{\mathrm{t}+1} & : \mathrm{t}+1 \text { dönemindeki cari spot kurun logaritması } \\
\mathrm{r}_{\mathrm{t}} & : \text { t dönemindeki yurtiçi faiz oranının logaritması } \\
\mathrm{r}_{\mathrm{t}}^{*} & : \text { t dönemindeki yurtdışı faiz oranının logaritması }
\end{array}
$$


$\beta_{0}$, sabit bir risk primi ve işlem maliyetleri ölçüsüdür. $\beta_{1}$, faiz oranı farklılığı katsayısıdır. $u_{t+1}$, rasyonel beklenti tahmin hatalarını ve güvencesiz faiz paritesinin geçerliliğini engelleyici açıklanamayan etkileri yansıtan hata terimidir. Güvencesiz faiz paritesinin geçerli olabilmesi için $\beta_{0}=0$ ve $\beta_{1}=1$ koşullarının sağlanması gerekmektedir. Bu koşulun sağlanması durumunda, karar birimleri döviz kurlarında bir değer kaybı beklemedikleri sürece, yurtiçi faiz oranı yurtdışı faiz oranından daha yüksek olamayacaktır (Bhatti, 2014, s. 234).

Çalışmada faiz oranı paritesi hipotezinin uzun dönem geçerliliği zaman serisi ve panel veri analizleri ile test edilecektir. Zaman serisi analizinde serilerin durağanlık dereceleri göz önünde bulundurularak ARDL sınır testine yer verilecektir. ARDL sınır testi, serilere aynı derecede durağanlık koşulu getirmeden eşbütünleşme analizi imkanı tanımaktadır. Seriler arasında eşbütünleşme ilişkisinin bulunması durumunda, faiz paritesinin ilgili ülkeler için geçerli olacağı sonucuna ulaşılacaktır. Panel veri analizinde ise benzer şekilde serilerin durağanlık düzeyleri göz önünde bulundurularak rassal etkili model sonuçlarına yer verilecektir. Rassal etkili modelin tahmini sonrasında elde edilecek katsayının hipoteze uygunluğu araştırılacaktır. Çalışmada zaman serisi ve panel veri analiz sonuçlarının karşılaştırılması amaçlanmaktadır.

Etkin Piyasa Hipotezi Iç̧in Test Yöntemleri: Etkin piyasa hipotezi literatürde çoğunlukla zayıf ve yarı güçlü formda test edilmektedir. Bu çalışmada etkin piyasa hipotezi yarı güçlü formda test edilecektir. Yarı-güçlü etkinlik modeli aşağıda yer alan eşitlik yardımıyla gösterilebilir (Pilbeam, 2005, s. 205):

$$
\begin{aligned}
& \qquad s_{t+1}=\beta_{0}+\beta_{1} f_{t}+u_{t+1} \\
& s_{t+1}: t+1 \text { dönemindeki cari spot kurun logaritması } \\
& \mathrm{f}_{\mathrm{t}}: \mathrm{t} \text { dönemindeki forward kurun logaritması }
\end{aligned}
$$

$\beta_{0}$ sabit terimi, $\beta_{1}$ açıklayıcı değişken için katsayı parametresini, $u_{t+1} t+1$ dönemi hata terimini ifade etmektedir. Piyasa etkinliği hipotezi modelinin geçerli olabilmesi için $\beta_{0}=0$ ve $\beta_{1}=1$ koşulunun sağlanması gerekmektedir. Bu hipotezlerin sağlanması durumunda, döviz piyasasının etkin olduğu ve hiçbir risk priminin yer almadığı söylenebilir.

Çalışmada etkin piyasa hipotezinin yarı güçlü formda uzun dönem geçerliliği zaman serisi analizi ile test edilecektir. Illk olarak serilerin durağanlık derecelerini ortaya koymak için Augmented Dickey Fuller (ADF) ve Phillips-Perron (PP) birim kök testlerine yer verilecektir. Serilerin aynı derecede durağanlık koşulunu sağlaması sonucunda Johansen (1988) eşbütünleşme analizi uygulanacaktır.

\section{Veri Seti}

Çalışma 2003Q1-2015Q4 çeyreklik dönemleri kapsamaktadır. Spot döviz kuru olarak ABD Doları temel alınmıştır. Türkiye dışındaki tüm ülkeler için yurtiçi faiz oranı verileri para piyasası faiz oranları ile analize dâhil edilmiştir. Türkiye'nin para piyasası faiz oranlarının bulunmaması nedeniyle, para politikası faiz oranı kullanılmıştır. Yurtdışı faiz oranı ise ABD’nin para piyasası faiz oranını ifade etmektedir. Bütün veriler IMF International Financial Statistics (IFS) veri tabanından temin edilmiştir. Diğer taraftan forward kuru verisi, Pilbeam (2005: 22) ${ }^{4 \prime}$ nin işaret ettiği formül yardımıyla tarafımdan derlenmiştir.

\footnotetext{
${ }^{4}$ Çeyreklik veriler doğrultusunda forward kur hesaplama yöntemi: $\mathrm{F}=\frac{\left[\left(\mathrm{i}_{\mathrm{F}}-\mathrm{i}\right) / 4\right] \mathrm{S}}{[1+(\mathrm{i} / 4)}+\mathrm{S}$.
} 
Tablo 3: Dâhil Edilen Ülkeler ve Uyguladıkları Döviz Kuru Rejimleri

\begin{tabular}{|c|c|c|}
\hline Ülkeler & Para Birimi & Döviz Kuru Rejimleri \\
\hline Brezilya & Real & $\begin{array}{l}\text { 2003-2009: Esnek Kur Politikası } \\
\text { 2009-2015: Yönetimli Dalgalanma }\end{array}$ \\
\hline Çek Cumhuriyeti & Koruna & $\begin{array}{l}\text { 2003-2008: Yönetimli Dalgalanma } \\
\text { 2008-2014: Esnek Kur Politikası } \\
\text { 2014-2015: Diğer Yönetimli Düzenleme }\end{array}$ \\
\hline Endonezya & Rupiah & $\begin{array}{l}2003-2011: \text { Yönetimli Dalgalanma } \\
2011 \quad \text { : İstikrar Sağlayıcı Düzenleme } \\
2012 \quad \text { : Yönetimli Dalgalanma } \\
2013 \quad \text { : Sürünen Parite Benzeri Düzenleme } \\
2014-2015: \text { Yönetimli Dalgalanma }\end{array}$ \\
\hline Filipinler & Peso & $\begin{array}{l}\text { 2003-2009: Esnek Kur Politikası } \\
\text { 2009-2015: Yönetimli Dalgalanma }\end{array}$ \\
\hline Güney Afrika & Rand & $\begin{array}{l}\text { 2003-2009: Esnek Kur Politikası } \\
\text { 2009-2015: Yönetimli Dalgalanma }\end{array}$ \\
\hline Kolombiya & Peso & $\begin{array}{l}\text { 2003-2005: Esnek Kur Politikası } \\
\text { 2005-2015: Yönetimli Dalgalanma }\end{array}$ \\
\hline Kore & Won & $\begin{array}{l}\text { 2003-2010: Esnek Kur Politikası } \\
\text { 2010-2015: Yönetimli Dalgalanma }\end{array}$ \\
\hline Meksika & Peso & $\begin{array}{l}\text { 2003-2009: Esnek Kur Politikası } \\
\text { 2009-2012: Yönetimli Dalgalanma } \\
\text { 2012-2015: Esnek Kur Politikası }\end{array}$ \\
\hline Peru & Nuevo Sol & $\begin{array}{l}2003 \quad \text { : Esnek Kur Politikası } \\
2004-2011: \text { Yönetimli Dalgalanma } \\
2011 \quad \text { : Sürünen Parite Benzeri Düzenleme } \\
2012-2015: \text { Yönetimli Dalgalanma }\end{array}$ \\
\hline Polonya & Zloty & 2003-2015: Esnek Kur Politikası \\
\hline Rusya & Ruble & $\begin{array}{l}\text { 2003-2008: Yönetimli Dalgalanma } \\
\text { 2008-2015: Diğer Yönetimli Düzenleme } \\
2015 \quad \text { : Yönetimli Dalgalanma } \\
\end{array}$ \\
\hline $\begin{array}{l}\text { Şili } \\
\text { Tayland }\end{array}$ & $\begin{array}{l}\text { Peso } \\
\text { Baht }\end{array}$ & $\begin{array}{l}\text { 2003-2015: Esnek Kur Politikası } \\
\text { 2003-2015: Yönetimli Dalgalanma }\end{array}$ \\
\hline Türkiye & Lira & $\begin{array}{l}\text { 2003-2009: Esnek Kur Politikası } \\
2009 \quad \text { : Yönetimli Dalgalanma } \\
2010 \quad \text { : Esnek Kur Politikası } \\
\text { 2011-2015: Yönetimli Dalgalanma }\end{array}$ \\
\hline
\end{tabular}

Not: IMF tarafından 2003-2015 dönemleri arasında hazırlanan yıllık raporlar doğrultusunda tarafımdan derlenmiştir. IMF tarafından döviz kuru rejimi sınıflandırmasında 2009 yılında gidilen değişiklik göz önüne alınmıştır. ${ }^{5}$

Kaynak: IMF, Annual Report on Exchange Arrangements and Exchange Restrictions, 2003-2015.

Çalışmaya dâhil edilecek ülkeler $\mathrm{MSCl}^{6}$ Gelişen Piyasa Ekonomileri sınıflandırmasından hareketle belirlenmiştir. 2003-2015 dönemleri arasında serbest kur ve yönetimli dalgalanma uygulayan ülkeler ile birlikte bu rejimlere en yakın sistemi benimseyen ülkelerin çalışmaya dâhil edilmesi amaçlanmış ve 14 gelişen piyasa ekonomisinin bu kriterleri sağladığı görülmüştür.

\section{Güvencesiz Faiz Paritesi Modeli İçin Analiz Sonuçları}

\section{Zaman Serisi Analizi Sonuçları}

14 gelişen piyasa ekonomisi için spot döviz kuru farkı $\left(s_{t+1}-s_{t}\right)$ ve faiz oranı farkı $\left(r-r^{*}\right)$ serilerine yönelik ADF ve PP birim kök test sonuçları Tablo 4'te yer almaktadır.

\footnotetext{
${ }^{5}$ Döviz kuru rejiminde yaşanan değişiklikler için Habermeier (2009)'un çalışmasından yararlanılmıştır.

${ }^{6}$ MSCI: Morgan Stanley Capital International, Kaynak: https://www.msci.com/market-classification.
} 
Eskişehir Osmangazi Üniversitesi iiBF Dergisi

Tablo 4: Faiz Paritesi Modeli Iç̧in ADF ve PP Birim Kök Testi Sonuçları

\begin{tabular}{|c|c|c|c|c|c|}
\hline \multirow{2}{*}{ Ülkeler } & \multirow{2}{*}{ Seriler } & \multicolumn{2}{|c|}{ ADF Testi } & \multicolumn{2}{|c|}{ PP Testi } \\
\hline & & $\mathrm{t}$ istatistik & Olasılık & $\mathrm{t}$ istatistik & Olasılık \\
\hline \multirow{2}{*}{ Brezilya } & Döviz Kuru Farkı & $-7.486[0]^{*}$ & 0.000 & $-7.842[6]^{*}$ & 0.000 \\
\hline & Faiz Oranı Farkı & $-2.640[1]$ & 0.265 & $-2.062[4]$ & 0.554 \\
\hline \multirow{2}{*}{$\begin{array}{c}\text { Çek } \\
\text { Cumhuriyeti }\end{array}$} & Döviz Kuru Farkı & $-5.933[3]^{*}$ & 0.000 & $-16.331[44]^{*}$ & 0.000 \\
\hline & Faiz Oranı Farkı & $-2.764[3]$ & 0.218 & $-1.759[4]$ & 0.710 \\
\hline \multirow{2}{*}{ Endonezya } & Döviz Kuru Farkı & $-5.770[1]^{*}$ & 0.000 & $-6.203[5]^{*}$ & 0.000 \\
\hline & Faiz Oranı Farkı & $-2.866[3]$ & 0.183 & $-2.561[4]$ & 0.299 \\
\hline \multirow{2}{*}{ Filipinler } & Döviz Kuru Farkı & $-6.096[0]^{*}$ & 0.000 & $-6.122[3]^{*}$ & 0.000 \\
\hline & Faiz Oranı Farkı & $-2.059[1]$ & 0.555 & $-1.788[4]$ & 0.696 \\
\hline \multirow{2}{*}{ Güney Afrika } & Döviz Kuru Farkı & $-7.086[0]^{*}$ & 0.000 & $-7.123[3]^{*}$ & 0.000 \\
\hline & Faiz Oranı Farkı & $-2.985[3]$ & 0.147 & $-2.197[5]$ & 0.481 \\
\hline \multirow{2}{*}{ Kolombiya } & Döviz Kuru Farkı & $-7.673[0]^{*}$ & 0.000 & $-7.673[0]^{*}$ & 0.000 \\
\hline & Faiz Oranı Farkı & $-3.716[3]^{*}$ & 0.031 & $-2.069[4]$ & 0.551 \\
\hline \multirow{2}{*}{ Kore } & Döviz Kuru Farkı & $-6.178[0]^{*}$ & 0.000 & $-6.187[2]^{*}$ & 0.000 \\
\hline & Faiz Oranı Farkı & $-2.446[2]$ & 0.352 & $-1.791[4]$ & 0.694 \\
\hline \multirow{2}{*}{ Meksika } & Döviz Kuru Farkı & $-6.685[0]^{*}$ & 0.000 & $-6.691[4]^{*}$ & 0.000 \\
\hline & Faiz Oranı Farkı & $-2.584[3]$ & 0.289 & $-2.145[4]$ & 0.509 \\
\hline \multirow{2}{*}{ Peru } & Döviz Kuru Farkı & $-6.211[0]^{*}$ & 0.000 & $-6.131[5]^{*}$ & 0.000 \\
\hline & Faiz Oranı Farkı & $-3.167[1]$ & 0.103 & $-2.370[2]$ & 0.390 \\
\hline \multirow{2}{*}{ Polonya } & Döviz Kuru Farkı & $-5.416[3]^{*}$ & 0.000 & $-7.612[16]^{*}$ & 0.000 \\
\hline & Faiz Oranı Farkı & $-2.510[2]$ & 0.322 & $-1.846[5]$ & 0.667 \\
\hline \multirow{2}{*}{ Rusya } & Döviz Kuru Farkı & $-3.471[2]$ & 0.054 & $-6.435[1]^{*}$ & 0.000 \\
\hline & Faiz Oranı Farkı & $-2.320[1]$ & 0.416 & $-2.908[3]$ & 0.169 \\
\hline \multirow{2}{*}{ Şili } & Döviz Kuru Farkı & $-7.861[0]^{*}$ & 0.000 & $-8.871[11]^{*}$ & 0.000 \\
\hline & Faiz Oranı Farkı & $-4.051[3]^{*}$ & 0.014 & $-2.475[2]$ & 0.339 \\
\hline \multirow{2}{*}{ Tayland } & Döviz Kuru Farkı & $-7.306[0]^{*}$ & 0.000 & $-7.371[5]^{*}$ & 0.000 \\
\hline & Faiz Oranı Farkı & $-2.157[1]$ & 0.502 & $-1.905[3]$ & 0.637 \\
\hline \multirow{2}{*}{ Türkiye } & Döviz Kuru Farkı & $-6.414[1]^{*}$ & 0.000 & $-9.640[7]^{*}$ & 0.000 \\
\hline & Faiz Oranı Farkı & $-2.979[2]$ & 0.149 & $-2.426[4]$ & 0.363 \\
\hline
\end{tabular}

Not: ADF ve PP test istatistik değerleri, düzey değerlerinde sabit terimli ve trendli modellerin sonuçlarını yansıtmaktadır. ADF istatistik değerlerinde yer alan köşeli parantez içindeki değerler Akaike Bilgi Kriterine (AIC) göre belirlenmiş optimum gecikme uzunluklarını, PP istatistik değerlerinde yer alan köşeli parantez içindeki değerler ise Newey-West Bandwith belirleyicisine göre elde edilen band genişliğini göstermektedir. (*), işareti serilerin MacKinnon (1996)'ya göre $\% 5$ düzeyinde durağanlığını ifade etmektedir.

Tablo 4'te yer alan ADF birim kök testi sonuçları, Şili ve Kolombiya'nın döviz kuru farkı ve faiz oranı farkı serilerinin düzey değerlerinde durağan, Rusya'nın döviz kuru farkı ve faiz oranı farkı serilerinin ise düzey değerlerinde durağan olmadığını ortaya koymaktadır. Geriye kalan 11 ülkenin tamamı için döviz kuru farkı serilerinin düzey değerlerinde durağan ve faiz oranı farkı serilerinin ise düzey değerlerinde durağan olmadığı görülmektedir.

PP birim kök testi sonuçları ise Şili ve Kolombiya'da dâhil olmak üzere 14 ülkenin tamamı için döviz kuru farkı serilerinin düzey değerlerinde durağan ve faiz oranı farkı serilerinin ise düzey değerlerinde durağan olmadığını ortaya koymaktadır. PP birim kök testi ile faiz oranı farkı serilerinin tamamının birinci farkta durağan olduğu tespit edilmiştir.

ARDL sınır testi yaklaşımı serilere aynı seviyede durağanlık koşulu getirmeksizin eşbütünleşme analizi imkânı tanımaktadır. PP birim kök testi sonuçlarından hareketle 14 ülkenin tamamı için ARDL sınır testi sonuçları Tablo 5'te ve uzun dönem ilişkisine sahip ülkeler için tanılayıcı istatistikler ise Tablo 6'da yer almaktadır. 
Tablo 5: Faiz Paritesi Modeli için ARDL Sınır Testi Sonuçları

\begin{tabular}{|c|c|c|c|c|c|}
\hline \multirow{2}{*}{ Ülkeler } & \multirow{2}{*}{ k } & \multirow{2}{*}{$\begin{array}{c}\text { ARDL } \\
\text { Modeli }\end{array}$} & \multirow{2}{*}{ F test istatistiği } & \multicolumn{2}{|c|}{ Uzun Dönem Katsayılar } \\
\hline & & & & $\beta_{0}$ & $\beta_{1}$ \\
\hline Brezilya & 1 & $(1,1)$ & $15.345^{*}$ & -0.069 & $0.038^{*}$ \\
\hline Çek Cumhuriyeti & 1 & - & 1.157 & - & - \\
\hline Endonezya & 1 & - & 1.538 & - & - \\
\hline Filipinler & 1 & $(1,1)$ & 13.724* & -0.017 & 0.013 \\
\hline Güney Afrika & 1 & $(2,11)$ & $14.651^{*}$ & $-0.063^{*}$ & $0.056^{*}$ \\
\hline Kolombiya & 1 & $(1,10)$ & $8.038^{*}$ & -0.061 & 0.057 \\
\hline Kore & 1 & - & 2.945 & - & - \\
\hline Meksika & 1 & $(1,1)$ & $14.524^{*}$ & -0.003 & 0.010 \\
\hline Peru & 1 & $(1,1)$ & $11.243^{*}$ & -0.011 & 0.011 \\
\hline Polonya & 1 & - & 1.373 & - & - \\
\hline Rusya & 1 & - & 2.969 & - & - \\
\hline Şili & 1 & $(1,0)$ & $18.442^{*}$ & -0.020 & $0.024 *$ \\
\hline Tayland & 1 & $(1,0)$ & $17.582^{*}$ & -0.011 & 0.015 \\
\hline Türkiye & 1 & $(2,0)$ & $18.016^{*}$ & -0.015 & 0.018 \\
\hline
\end{tabular}

Not: Kritik değerler Pesaran vd. (2001)'ten alınmıştır. "k", bağımsız değişken sayısını göstermektedir. (*) işareti, katsayıların \%5'lik kritere göre anlamlılığını göstermektedir.

Hesaplanan F test istatistik değeri \%5 anlamlılık düzeyinde Pesaran vd. (2001) tarafından belirlenen üst sınır değerinden büyük olması durumunda $\mathrm{H}_{0}$ hipotezi reddedilmekte ve seriler arasında eşbütünleşme ilişkisinin bulunduğu söylenebilmektedir. Bu açıklamadan hareketle Brezilya, Filipinler, Güney Afrika, Kolombiya, Meksika, Peru, Şili, Tayland ve Türkiye için uzun dönemli bir ilişkinin bulunduğu sonucu elde edilmektedir. Buna karşın Çek Cumhuriyeti, Endonezya, Kore, Polonya ve Rusya için eşbütünleşme ilişkisine rastlanılmamıştır. Elde edilen uzun dönem katsayılardan ise sadece Güney Afrika'nın istatistiksel olarak anlamlı olduğu görülmektedir. Sonuç olarak tüm ülkeler için güvencesiz faiz paritesinin geçerli olmadığı söylenebilir. 
Eskişehir Osmangazi Üniversitesi iiBF Dergisi

Tablo 6 -Uzun Dönemli ilişkiye Sahip Ülkeler Için Tanılayıcı İstatistikler

\begin{tabular}{|c|c|c|c|c|c|}
\hline & & & Otokorelasyon & Değişen Varyans & Normallik \\
\hline Ülkeler & $\mathrm{R}^{2}$ & F-istatistik & $\begin{array}{c}\text { Breusch-Godfrey LM } \\
\text { Testi }\end{array}$ & $\begin{array}{l}\text { Breusch-Pagan- } \\
\text { Godfrey Testi }\end{array}$ & $\begin{array}{c}\text { Jarque-Bera } \\
\text { Testi }\end{array}$ \\
\hline Brezilya & 0.58 & $\begin{array}{l}20.758 \\
(0.000)\end{array}$ & $\begin{array}{l}0.409 \\
(0.82)\end{array}$ & $\begin{array}{l}5.700 \\
(0.13)\end{array}$ & $\begin{array}{l}4.339 \\
(0.11)\end{array}$ \\
\hline Filipinler & 0.49 & $\begin{array}{l}14.732 \\
(0.000)\end{array}$ & $\begin{array}{l}0.757 \\
(0.68)\end{array}$ & $\begin{array}{l}6.738 \\
(0.08)\end{array}$ & $\begin{array}{l}2.149 \\
(0.34)\end{array}$ \\
\hline Güney Afrika & 0.74 & $\begin{array}{c}5.466 \\
(0.000)\end{array}$ & $\begin{array}{l}0.954 \\
(0.62)\end{array}$ & $\begin{array}{l}11.707 \\
(0.63)\end{array}$ & $\begin{array}{l}4.507 \\
(0.11)\end{array}$ \\
\hline Kolombiya & 0.77 & $\begin{array}{c}7.877 \\
(0.000)\end{array}$ & $\begin{array}{l}4.113 \\
(0.13)\end{array}$ & $\begin{array}{l}5.935 \\
(0.92)\end{array}$ & $\begin{array}{l}11.467 \\
(0.00)^{*}\end{array}$ \\
\hline Meksika & 0.58 & $\begin{array}{l}21.331 \\
(0.000)\end{array}$ & $\begin{array}{l}1.448 \\
(0.48)\end{array}$ & $\begin{array}{l}10.922 \\
(0.01)^{*}\end{array}$ & $\begin{array}{l}0.390 \\
(0.82)\end{array}$ \\
\hline Peru & 0.48 & $\begin{array}{l}14.048 \\
(0.000)\end{array}$ & $\begin{array}{l}1.041 \\
(0.59)\end{array}$ & $\begin{array}{l}6.722 \\
(0.08)\end{array}$ & $\begin{array}{c}7.455 \\
(0.02)^{*}\end{array}$ \\
\hline Şili & 0.54 & $\begin{array}{l}28.088 \\
(0.000)\end{array}$ & $\begin{array}{l}1.152 \\
(0.56)\end{array}$ & $\begin{array}{l}2.132 \\
(0.34)\end{array}$ & $\begin{array}{l}0.113 \\
(0.94)\end{array}$ \\
\hline Tayland & 0.53 & $\begin{array}{l}25.909 \\
(0.000)\end{array}$ & $\begin{array}{l}0.253 \\
(0.88)\end{array}$ & $\begin{array}{l}0.283 \\
(0.87)\end{array}$ & $\begin{array}{l}0.564 \\
(0.75)\end{array}$ \\
\hline Türkiye & 0.52 & $\begin{array}{l}16.099 \\
(0.000)\end{array}$ & $\begin{array}{l}3.304 \\
(0.19)\end{array}$ & $\begin{array}{l}1.827 \\
(0.61)\end{array}$ & $\begin{array}{l}2.794 \\
(0.25)\end{array}$ \\
\hline
\end{tabular}

Not: $\left({ }^{*}\right)$ işareti, katsayıların \%5'lik kritere göre anlamlılığını göstermektedir. Breusch-Godfrey LM testi için hipotezler $\mathrm{H}_{0}$ : Otokorelasyon sorunu yoktur, $\mathrm{H}_{1}$ : Otokorelasyon sorunu vardır. Breusch-Pagan-Godfrey testi için hipotezler $\mathrm{H}_{0}$ : Değişen varyans sorunu yoktur, $\mathrm{H}_{1}$ : Değişen varyans sorunu vardır. Jarque-Bera testi için hipotezler $\mathrm{H}_{0}$ : Seriler normal dağılıma sahiptir, $\mathrm{H}_{1}$ : Seriler normal dağılıma sahip değildir.

Tablo 6'da döviz kuru ile faiz oranı serileri arasında uzun dönemli ilişkiye sahip olan ülkeler için tanılayıcı istatistiklere yer verilmektedir. Breusch-Godfrey LM testi ülkelerin tamamında otokorelasyon sorunun bulunmadığına işaret etmektedir. Breusch-Pagan-Godfrey Testi ise Meksika dışındaki ülkelerin tamamında değişen varyans sorununun bulunmadığını ortaya koymaktadır. Son olarak Jarqua-Bera normallik testi Peru ve Kolombiya'nın serilerinin normal dağılıma sahip olmadığını ifade etmektedir. Söz konusu bulgulardan hareketle Peru, Meksika ve Kolombiya için eşbütünleşme ilişkisini işaret eden ARDL sonuçları yorumlanamaz niteliktedir.

Tahmin edilen ARDL modellerinde yapısal değişimin varlığını araştırmaya yönelik olarak CUSUM testlerine başvurulmaktadır. Uzun dönemli ilişkiye sahip ve aynı zamanda tanılayıcı istatistikleri anlamlı olan 6 ülke için (Brezilya, Filipinler, Güney Afrika, Şili, Tayland ve Türkiye) için CUSUM testi sonuçları Şekil 1'de yer almaktadır. 
Şekil 1: CUSUM Testi Sonuçları

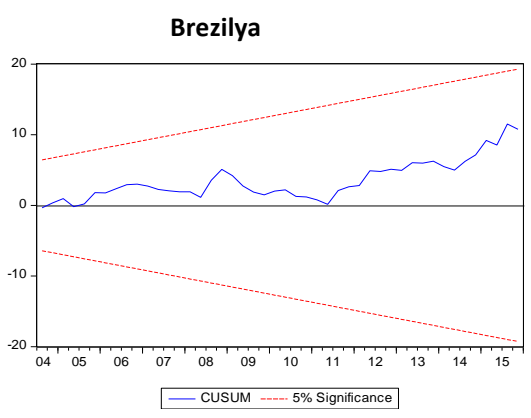

Filipinler

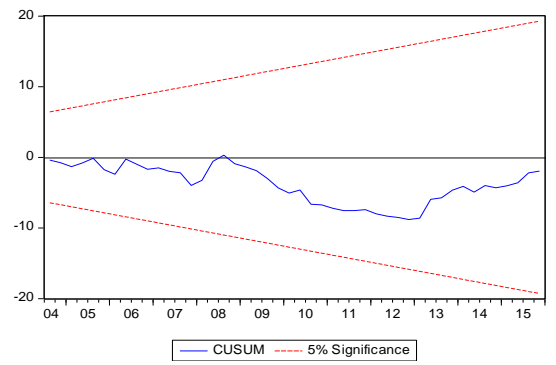

Güney Afrika

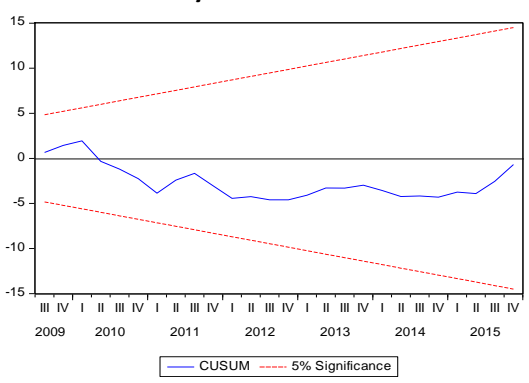

Şili

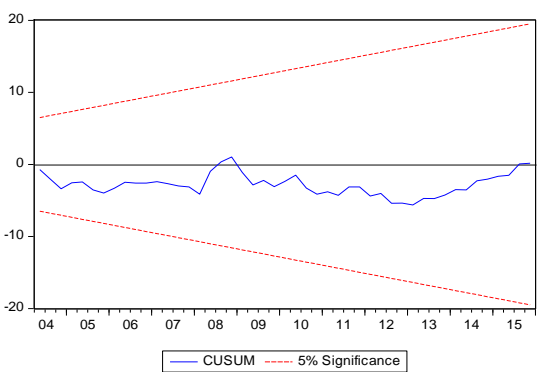

Tayland

Türkiye
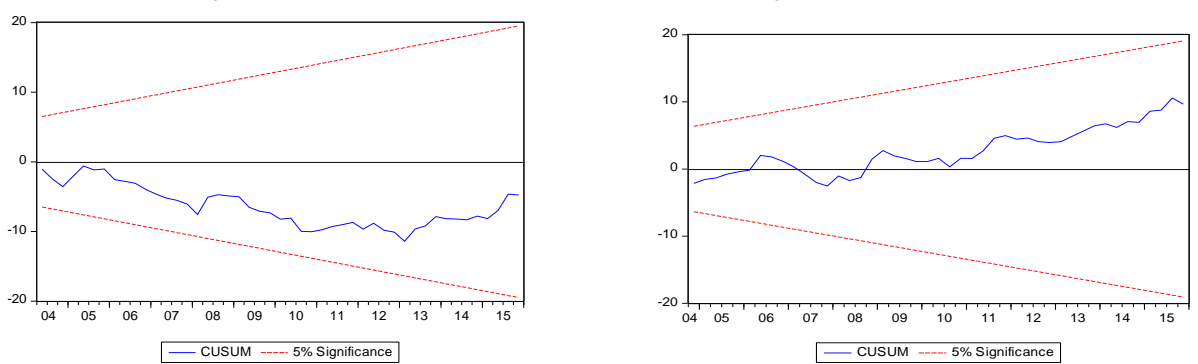

Şekil 1'de yer alan sonuçlar Brezilya, Filipinler, Güney Afrika, Şili, Tayland ve Türkiye için tespit edilen modellerin tahmin dönemleri itibari ile kararlı olduğunu ortaya koymaktadır. Diğer bir ifade ile söz konusu dönemlerde yapısal kırılmaların bulunmadığı söylenebilir.

\section{Panel Veri Analizi Sonuçları}

Spot döviz kuru farkı $\left(s_{t+1}-s_{t}\right)$ ve faiz oranı farkı $\left(r-r^{*}\right)$ serilerine yönelik panel birim kök testi sonuçları Tablo 7'da yer almaktadır. 
Eskişehir Osmangazi Üniversitesi iiBF Dergisi

Tablo 7: Faiz Paritesi Modeli Için Panel Birim Kök Testi Sonuçları

\begin{tabular}{lcccc}
\hline \multicolumn{4}{c}{ DÜZEY DEĞERLER } \\
\hline & \multicolumn{2}{c}{ Döviz Kuru Farkı } & \multicolumn{2}{c}{ Faiz Oranı Farkı } \\
\cline { 2 - 5 } & İstatistik & Olasılık & İstatistik & Olasılık \\
\hline Levin, Lin \& Chu & -18.942 & $0.000^{*}$ & -2.280 & $0.011^{*}$ \\
Breitung & -12.598 & $0.000^{*}$ & -4.702 & $0.000^{*}$ \\
Im, Pesaran \& Shin & -19.656 & $0.000^{*}$ & -2.970 & $0.002^{*}$ \\
ADF Fisher & 320.081 & $0.000^{*}$ & 48.005 & $0.010^{*}$ \\
PP Fisher & 396.084 & $0.000^{*}$ & 21.095 & 0.821 \\
\hline
\end{tabular}

Not: * işareti serilerin \%5 düzeyinde istatistiksel olarak anlamlı olduğunu ifade etmektedir. Levin, Lin \& Chu testinde Barlett tahmincisi ve Newey-West yöntemi kullanılmıştır. Optimum gecikme uzunluğu Akaike Bilgi Kriterine göre belirlenmiştir.

Tablo 7'da yer alan panel birim kök testi sonuçları logaritmik olarak ifade edilen döviz kuru farkı ve faiz oranı farkı serileri için düzey değerlerinde durağanlık koşulunun sağlandığını ortaya koymaktadır. Buradan hareketle söz konusu serilere yönelik sabit ve rassal etkili modellere yer verilebilir.

Tablo 8'de yer alan $\mathrm{F}$ test sonuçları modelin Pool analizi ile test edilmesi gerekliliğine işaret etmektedir. Diğer taraftan modelin sabit etkiler ve rassal etkiler tahmincilerinden hangisi ile test edileceğine karar vermek için Hausman testine başvurulmaktadır (Asteriou ve Hall, 2011: 418). Hausman olasılık değeri $\mathrm{H}_{0}$ hipotezini kabul etmektedir. Bu nedenle analizde rassal etkili model sonuçlarına yer verilmektedir.

Tablo 8: Faiz Paritesi Modeli Için Rassal Etkili Model Tahmin Sonuçları (2003Q1-2015Q4)

\begin{tabular}{|c|c|c|c|c|}
\hline Değişkenler & Katsayılar & Standart Hata & $\begin{array}{l}\text { t-istatistik } \\
\text { Değerleri }\end{array}$ & $\begin{array}{c}\text { Olasılık } \\
\text { Değerleri }\end{array}$ \\
\hline c & -0.008 & 0.004 & -1.863 & 0.063 \\
\hline$\left(r-r^{*}\right)$ & 0.010 & 0.003 & $3.249^{*}$ & 0.001 \\
\hline$R^{2}=0.015$ & \multicolumn{4}{|c|}{ F-istatistik $=10.675 *(0.001)$} \\
\hline $\mathrm{F}$ test $=0.390$ & \multicolumn{4}{|c|}{ Hausman Test $=0.167$} \\
\hline Olasılık $=0.973$ & \multicolumn{4}{|c|}{ Olasılık $=0.683$} \\
\hline Ülke Sayısı = 14 & \multicolumn{4}{|c|}{ Gözlem Sayısı = 714} \\
\hline Değişkenler & \multicolumn{3}{|c|}{ Wald Test İstatistiği } & Olasılık Değeri \\
\hline c & 0 & \multicolumn{2}{|c|}{3.471} & 0.062 \\
\hline$\left(r-r^{*}\right)$ & 1 & \multicolumn{2}{|c|}{92337.47} & 0.000 \\
\hline
\end{tabular}

Not: $\left({ }^{*}\right)$, işareti serilerin serilerin \%5 düzeyinde anlamlı olduğunu ifade etmektedir. Modelde değişen varyans ve otokorelasyon sorunlarını dikkate alan, PSCE (panel-corrected standard error) yöntemi kullanılmıştır.

Rassal etkili model sonuçlarına göre \%5 anlamlılık seviyesinde yurtiçi ve yurtdışı faiz oranı farkı serisinin $\left(r-r^{*}\right)$ istatistiki olarak anlamlı, c katsayısının ise anlamsız olduğu görülmektedir. Temel hipotezimiz $\beta_{0}=0$ ve $\beta_{1}=1$ koşullarının sağlanması yönündedir. Bu hipotezlerin istatistiksel olarak geçerli olup olmadığı Wald testi ile analiz edilmiştir. c değişkeni için hesaplanan Wald test istatistiği 3.471 olarak elde edilmiştir. Bu değer \%5 anlamlılık seviyesinde $\chi^{2}$ tablo değeri 
olan 3.84 değerinden küçük olduğu için $\beta_{0}=0$ temel hipotezi $\% 5$ anlamlılık seviyesinde reddedilememektedir. $\left(r-r^{*}\right)$ değişkeni için hesaplanan Wald test istatistiği ise 92337.47 olarak elde edilmiştir. Bu değer \%5 anlamlılık seviyesinde $\chi^{2}$ tablo değeri olan 3.84 değerinden büyük olduğu için $\beta_{1}=1$ temel hipotezi \%5 anlamlılık seviyesinde reddedilmektedir. Bu anlamda rassal etkili model sonuçlarına göre, güvencesiz faiz paritesinin uzun dönemli geçerliliğinin sağlanamadığı söylenebilir.

\section{Etkin Piyasa Hipotezi Modeli İçin Analiz Sonuçları}

14 gelişen piyasa ekonomisinin $A B D$ doları temelinde yer alan spot döviz kurları ve forward döviz kurlarına yönelik ADF ve PP birim kök test sonuçları Tablo 8'de yer almaktadır.

Tablo 9: Piyasa Etkinliği Hipotezi ADF ve PP Birim Kök Testi Sonuçları

\begin{tabular}{|c|c|c|c|c|c|c|}
\hline \multirow{2}{*}{ Ülkeler } & \multirow{2}{*}{\multicolumn{2}{|c|}{ Seriler }} & \multicolumn{2}{|c|}{ ADF Testi } & \multicolumn{2}{|c|}{ PP Testi } \\
\hline & & & $\mathrm{t}$ istatistik & Prob. & t istatistik & Prob. \\
\hline \multirow{2}{*}{ Brezilya } & Spot Kur & (BRL/USD) & $-0.463[0]$ & 0.982 & $0.168[6]$ & 0.997 \\
\hline & Forward kur & & $0.192[0]$ & 0.997 & $1.093[6]$ & 0.999 \\
\hline \multirow{2}{*}{ Çek Cumhuriyeti } & Spot Kur & (CZK/USD) & $-1.571[0]$ & 0.791 & $-1.171[10]$ & 0.906 \\
\hline & Forward Kur & & $-1.534[0]$ & 0.805 & $-1.125[10]$ & 0.915 \\
\hline \multirow{2}{*}{ Endonezya } & Spot Kur & (IDR/USD) & $-1.973[7]$ & 0.600 & $-1.541[1]$ & 0.802 \\
\hline & Forward Kur & & $-0.898[7]$ & 0.947 & $-0.886[2]$ & 0.950 \\
\hline \multirow{2}{*}{ Filipinler } & Spot Kur & (PHP/USD) & $-0.935[0]$ & 0.944 & $-1.344[3]$ & 0.865 \\
\hline & Forward Kur & & $-1.031[0]$ & 0.930 & $-1.500[4]$ & 0.817 \\
\hline \multirow{2}{*}{ Güney Afrika } & Spot Kur & (ZAR/USD) & $-1.701[0]$ & 0.736 & $-1.727[1]$ & 0.725 \\
\hline & Forward Kur & & $-2.319[0]$ & 0.416 & $-2.313[1]$ & 0.419 \\
\hline \multirow{2}{*}{ Kolombiya } & Spot Kur & (COP/USD) & $-0.416[0]$ & 0.984 & $-0.276[1]$ & 0.989 \\
\hline & Forward Kur & & $-0.072[0]$ & 0.994 & $0.152[1]$ & 0.997 \\
\hline \multirow{2}{*}{ Kore } & Spot Kur & (KRW/USD) & $-2.348[1]$ & 0.401 & $-2.495[3]$ & 0.329 \\
\hline & Forward Kur & & $-2.468[1]$ & 0.342 & $-2.200[3]$ & 0.479 \\
\hline \multirow{2}{*}{ Meksika } & Spot Kur & (MXN/USD) & $-2.577[1]$ & 0.292 & $-2.212[0]$ & 0.473 \\
\hline & Forward Kur & & $-2.672[1]$ & 0.252 & $-2.531[1]$ & 0.313 \\
\hline \multirow{2}{*}{ Peru } & Spot Kur & (PEN/USD) & $0.548[0]$ & 0.999 & $1.279[6]$ & 0.999 \\
\hline & Forward Kur & & $-0.052[0]$ & 0.994 & $0.102[4]$ & 0.997 \\
\hline \multirow{2}{*}{ Polonya } & Spot Kur & (PLN/USD) & $-2.417[1]$ & 0.367 & $-1.861[7]$ & 0.660 \\
\hline & Forward Kur & & $-2.533[1]$ & 0.312 & $-1.729[6]$ & 0.724 \\
\hline \multirow{2}{*}{ Rusya } & Spot Kur & (RUB/USD) & $-0.332[3]$ & 0.987 & $-0.078[1]$ & 0.994 \\
\hline & Forward Kur & & $-0.159[3]$ & 0.992 & $-0.067[0]$ & 0.994 \\
\hline \multirow{2}{*}{ Şili } & Spot Kur & (CLP/USD) & $-1.619[0]$ & 0.772 & $-1.344[4]$ & 0.865 \\
\hline & Forward Kur & & $-1.191[0]$ & 0.902 & $-0.667[6]$ & 0.970 \\
\hline \multirow{2}{*}{ Tayland } & Spot Kur & (THB/USD) & $-0.711[0]$ & 0.967 & $-0.565[4]$ & 0.977 \\
\hline & Forward Kur & & $-0.349[0]$ & 0.987 & $-0.082[4]$ & 0.994 \\
\hline \multirow{2}{*}{ Türkiye } & Spot Kur & (TRY/USD) & $-2.522[0]$ & 0.317 & $-2.551[1]$ & 0.304 \\
\hline & Forward Kur & & $-1.654[0]$ & 0.757 & $-1.654[0]$ & 0.757 \\
\hline
\end{tabular}

Not: ADF ve PP test istatistik değerleri, düzey değerlerinde sabit terimli ve trendli modellerin sonuçlarını yansıtmaktadır. ADF istatistik değerlerinde yer alan köşeli parantez içindeki değerler Akaike Bilgi Kriterine (AIC) göre belirlenmiş optimum gecikme uzunluklarını, PP istatistik değerlerinde yer alan köşeli parantez içindeki değerler ise Newey-West Bandwith belirleyicisine göre elde edilen band genişliğini göstermektedir. $\left({ }^{*}\right)$, işareti serilerin MacKinnon (1996)'ya göre $\% 5$ düzeyinde durağanlığını ifade etmektedir. 
ADF ve PP birim kök testi sonuçları 14 ülkenin tamamı için düzey değerlerinde durağanlık şartını reddetmekte, diğer bir ifade ile $\mathrm{H}_{0}$ hipotezi kabul edilmektedir. Serilerin tamamının PP birim kök testine göre biricini farkta durağan olduğu tespit edilmiştir. Tüm değişkenlerin aynı seviyede durağan olmaları, değişkenler arasında uzun dönem denge ilişkisi (eş-bütünleşme) araştırılmasına imkân vermektedir. Buradan hareketle Johansen eşbütünleşme analizi sonuçlarına yer verilebilir.

Tablo 10: Piyasa Etkinliği Hipotezi Johansen Eşbütünleşme Analizi Sonuçları

\begin{tabular}{|c|c|c|c|c|}
\hline Ülkeler & $\begin{array}{l}\text { Gecikme Uzun- } \\
\text { luğu }\end{array}$ & Eşbütütünleşme Sayısı & Trace Testi & $\begin{array}{c}\text { Maximum Eigenva- } \\
\text { lue }\end{array}$ \\
\hline \multirow{2}{*}{ Brezilya } & \multirow{2}{*}{3} & $r=0$ & 12.595 & 12.476 \\
\hline & & $r \leq 1$ & 0.112 & 0.118 \\
\hline \multirow{2}{*}{ Çek Cumhuriyeti } & \multirow{2}{*}{4} & $r=0$ & 14.023 & 10.600 \\
\hline & & $r \leq 1$ & 3.423 & 3.423 \\
\hline \multirow{2}{*}{ Endonezya } & \multirow{2}{*}{2} & $r=0$ & 10.803 & 10.533 \\
\hline & & $r \leq 1$ & 0.270 & 0.270 \\
\hline \multirow{2}{*}{ Filipinler } & \multirow{2}{*}{3} & $r=0$ & 8.000 & 4.593 \\
\hline & & $r \leq 1$ & 3.407 & 3.407 \\
\hline \multirow{2}{*}{ Güney Afrika } & \multirow{2}{*}{3} & $r=0$ & 11.372 & 10.067 \\
\hline & & $r \leq 1$ & 1.304 & 1.304 \\
\hline \multirow{2}{*}{ Kolombiya } & \multirow{2}{*}{3} & $r=0$ & 15.050 & 12.919 \\
\hline & & $r \leq 1$ & 2.131 & 2.131 \\
\hline \multirow{2}{*}{ Kore } & \multirow{2}{*}{3} & $r=0$ & 11.640 & 6.540 \\
\hline & & $r \leq 1$ & 5.100 & 5.100 \\
\hline \multirow{2}{*}{ Meksika } & \multirow{2}{*}{3} & $r=0$ & 8.002 & 7.848 \\
\hline & & $r \leq 1$ & 0.154 & 0.154 \\
\hline \multirow{2}{*}{ Peru } & \multirow{2}{*}{3} & $r=0$ & 12.772 & 10.438 \\
\hline & & $r \leq 1$ & 2.334 & 2.334 \\
\hline \multirow{2}{*}{ Polonya } & \multirow{2}{*}{3} & $r=0$ & 10.880 & 8.513 \\
\hline & & $r \leq 1$ & 2.368 & 2.368 \\
\hline \multirow{2}{*}{ Rusya } & \multirow{2}{*}{4} & $r=0$ & 10.728 & 10.342 \\
\hline & & $r \leq 1$ & 0.386 & 0.386 \\
\hline \multirow{2}{*}{ Şili } & \multirow{2}{*}{3} & $r=0$ & 13.907 & 11.348 \\
\hline & & $r \leq 1$ & 2.559 & 2.559 \\
\hline \multirow{2}{*}{ Tayland } & \multirow{2}{*}{3} & $r=0$ & 13.019 & 10.697 \\
\hline & & $r \leq 1$ & 2.322 & 2.322 \\
\hline \multirow{2}{*}{ Türkiye } & \multirow{2}{*}{2} & $r=0$ & $16.194^{*}$ & $15.897^{*}$ \\
\hline & & $r \leq 1$ & 0.297 & 0.297 \\
\hline
\end{tabular}

Not: $\left({ }^{*}\right)$ değerleri 0.05 düzeyinde hipotezin reddedildiğini göstermektedir. 2 numaralı modelin kullanıldığı Kore için iz testinin \%5 düzeyindeki kritik değerleri sırasıyla 20.262 ve 9.165 , maksimum özdeğer testinin $\% 5$ düzeyindeki kritik değerler sırasıyla 15.892 ve 9.165 'tir. 3 numaralı modelin kullanıldığı diğer ülkeler için iz testinin \%5 düzeyindeki kritik değerleri sırasıyla 15.495 ve 3.841, maksimum özdeğer testinin \%5 düzeyindeki kritik değerler sırasıyla 14.265 ve 3.841'dir. MacKinnon-Haug-Michelis (1999) p-değerleri kullanılmıştır. 
Tablo 10'da yer alan Johansen eşbütünleşme sonuçlarına göre, Türkiye dışındaki 13 gelişen piyasa ekonomilerinin tamamı için iz ve maksimum özdeğer testlerinin $\% 5$ anlamlılık düzeylerinde hiçbir eşbütünleşme vektörü bulunmamaktır. Türkiye için $\% 5$ anlamlılık düzeyine göre iz ve maksimum özdeğer testlerinde 1 adet eşbütünleşme vektörü bulunmaktadır. Bu sonuca göre Türkiye dışındaki ülkelere ait spot kur ve forward kurların uzun dönemde birlikte hareket etmediği söylenebilir.

Tablo 10'da yer alan Johansen eşbütünleşme analizilerine yönelik model tercihi Akaike Bilgi Kriteri'nin işaret ettiği modeller doğrultusunda belirlenmiştir. Bununla birlikte Pantula Prensibi de göz önünde bulundurularak analizler tekrar edilmiş ve benzer şekilde Türkiye dışında hiçbir ülke için eşbütünleşme ilişkisine rastlanılmamıştır.

\section{Sonuç ve Değerlendirme}

Günümüz finans piyasaları arasında gerçekleşen entegrasyon seviyesindeki artışlar, finansal sermayenin ülkeler arasında serbest bir şekilde hareket etmesine katkı sağlamaktadır. Küresel yatırımcılar risk ve getiri ilişkisini göz önünde bulundurarak hızlı ve anlık bir şekilde finans piyasalarında işlem gerçekleştirebilmektedir. Bu durum finansal piyasaların önemini yatırımcılar ve ekonomi politikası yapıcıları için her geçen gün arttırmaktadır.

Ekonomik karar birimleri açısından bakıldığında yatırımcı profili genel anlamda "en az risk ile en yüksek getiri" ilkesine dayanmaktadır. Risk algısını ortaya çıkaran temel faktör ise piyasalarda işlem gören döviz ve faiz gibi temel makro ekonomik değişkenlerin öngörülebilirliği ile ilgilidir. Bu anlamda finansal getirisi olan faiz ile döviz kurları arasındaki ilişkiyi açıklayan faiz oranı paritesi ve finans piyasalarının etkinlik dereceleri uluslararası finans literatürü için önemli iki yaklaşımı içermektedir.

Bu çalışmada faiz oranı paritesi ve etkin piyasa hipotezinin geçerliliği 14 gelişen piyasa ekonomisi için 2003Q1-2015Q4 çeyreklik dönemler itibariyle sırasıyla güvencesiz faiz oranı paritesi ve yarı-güçlü etkinlik modelleri ile test edilmiştir. Güvencesiz faiz oranı paritesi için zaman serisi ve panel veri analizlerine yer verilmiştir. Elde edilen bulgular güvencesiz faiz paritesinin gelişen piyasa ekonomileri için geçersiz olduğuna yöneliktir.

Yatırımcıların rasyonel beklentilere sahip ve riske karşı duyarsız olduğu varsayımından hareketle ele alınan yarı-güçlü etkinlik modeli için ise zaman serisi analizine yer verilmiştir. Elde edilen bulgular Türkiye dışında yer alan 13 ülke için hiçbir eşbütünleşme ilişkisinin bulunmadığına işaret etmektedir. Genel anlamda söz konusu ülkeler için piyasa etkinsizliği ön plandadır.

Gelişen piyasa ekonomileri finansal piyasalarının ve bu piyasadaki etkinlik derecelerinin yeteri kadar başarılı olmadı̆̆ı görülmektedir. Düşük tasarruf oranlarına sahip olan bu ülkeler, bir yandan yabancı sermaye akımları ile bu açığı kapatma çabasındayken, diğer yandan uluslararası piyasalarda oluşan küresel risk faktörlerine daha açık hale gelmektedir. Dolayısıyla bu ülkelere yönelik yapılacak çalışmaların, risk faktörlerini göz önünde bulundurularak yapılması daha etkin sonuçların elde edilmesine olanak sağlayacağı düşünülmektedir. 


\section{Eskişehir Osmangazi Üniversitesi iiBF Dergisi}

\section{Kaynaklar}

Adrangi, Bahram; Raffiee, Kambiz; Shank, T. M. (2007), “An Ex-Post Investigation of Interest Rate Parity in Asian Emerging Markets", International Business \& Economics Research Journal, Vol. 6 No. 2: 29-48.

Ahmad, Rubi; Rhee, S. G.; Wong, Y. M. (2012), “Foreign Exchange Market Efficiency Under Recent Crises: Asia-Pacific Focus", Journal of International Money and Finance, Vol. 31 No. 6: 1574-1592.

Arghyrou, Michael G.; Gregoriou, Andros; Kontonikas, Alexandros (2009), “Do Real Interest Rates Converge? Evidence from the European Union" Int. Fin. Markets, Inst. and Money, Vol. 19: 447-460.

Asteriou, Dimitrios; Hall, S. G. (2011), Applied Econometrics, $2^{\text {th }}$ Ed., London: Palgrave MacMillan.

Balke, Nathan S.; Wohar, Mark E. (1998), "Nonlinear Dynamics and Covered Interest Rate Parity”, Empirical Economics, Vol. 23: 535-559.

Bansal, Ravi; Dahlquist, Magnus (2000), "The Forward Premium Puzzle: Different Tales from Developed and Emerging Economies" Journal of International Economics, Vol. 51: 115-144.

Barkoulas, John; Baum, Christopher; Chakraborty, Atreya (2000), “Forward Premiums and Market Efficiency: Panel Unit-Root Evidence from the Term Structure of Forward Premiums", Boston College Working Papers: 1-20.

Batten, J. A.; Szilagyi, P. G. (2010), "Is Covered Interest Parity Arbitrage Extinct? Evidence from the Spot USD/Yen", Applied Economics Letters, Vol. 17 No. 3: 283-287.

Bhatti, Razzaque H. (2014), "The Existence of Uncovered Interest Parity in the CIS Countries", Economic Modelling, Vol. 40: 227-241.

Carvalho, Jaimilton V.; Sachsida, Adolfo; Loureiro, P. R. A.; Moreira, T. B. S. (2004), “Uncovered Interest Parity in Argentina, Brazil, Chile, and Mexico: A Unit Root Test Application with Panel Data" Review of Urban and Regional Development Studies, Vol. 16 No. 3: 263-269.

Chang, Hsu-Ling; Su, Chi W. (2015), “Uncovered Interest Parity and Monetary Integration in East Asian Countries Based on China", The Journal of International Trade \& Economic Development, Vol. 24 No. 4: 451-464.

Chin, Chang C.; Liang, H. M. (2009), "The Long-Run Uncovered Interest Rate Parity in View of A Trading Strategy", Applied Economics, Vol. 41, No.21: 2727-2739.

Choudhry, Taufiq (1999), “Re-Examining Forward Market Efficiency: Evidence from Fractional and Harris-Inder Cointegration Tests", International Review of Economics and Finance, Vol. 8: 433-453.

Committeri, Marco; Salvatore, Rossi; Santorelli, Andrea (1993), "Tests of Covered Interest Parity on the Euromarket with High-Quality Data", Applied Financial Economics, Vol. 3, No. 1: 89-93.

Copeland, Laurence (2005), Exchange Rates and International Finace, $4^{\text {th }}$ Ed., England: Bell \& Bain Limited.

Çiçek, Macide (2014). "A Cointegration Test for Turkish Foreign Exchange Market Efficiency", Asian Economic and Financial Review, 2014, Vol. 4 No. 4: 451-471.

Dickey, David. A.; Fuller, W. A. (1981), "Likelihood Ratio Statistics for Autoregressive Time Series with A Unit Root", Econometrica, Vol. 49 No. 4: 1057-1072.

Dunn, Jr. Robert M.; Mutti, J. H. (2000), International Economics, $5^{\text {th }}$ Ed., London: Routledge.

Dutt, Swarna D.; Ghosh, Dipak (1999), "An Empirical Examination of Exchange Market Efficiency”, Applied Economics Letters, Vol. 6 No. 2: 89-91.

Erdemlioglu, Deniz M. (2007), “A New Test of Uncovered Interest Rate Parity: Evidence from Turkey”, MPRA, Paper No.10787: 1-20.

Fama, Eugene F. (1970), "Efficient Capital Markets: A Review of Theory and Empirical Work", The Journal of Finance, Vol. 25 No. 2: 383-417.

Francis, Bill; Hasan, Iftekhar; Hunter, Delroy (2002), “Emerging Market Liberalization and the Impact On Uncovered Interest Rate Parity", Federal Reserve Bank of Atlanta, Working Paper No. 16: 1-54.

Fukuda, Shin-ichi (2016), “Regional Liquidity Risk and Covered Interest Parity During the Global Financial Crisis: Evidence from Tokyo, London, and New York", International Economic Journal, Vol. 30 No. 3: 339-359.

Gandolfo, Giancarlo (2002), International Finance and Open Economy Macro-Economics, New York: Springer-Verlag.

Gerber, James (2014), International Economics, $6^{\text {th }}$ Ed., New Jersey: Pearson Education.

Goh, Soo K.; Lim, G. C.; Nilss, Olekalns (2006), "Deviations from uncovered Interest Parity in Malaysia” Applied Financial Economics, Vol. 16 No. 10: 745-759. 
Guender, Alfred; Cook, Bevan (2011), “Monetary Policy Implementation and Uncovered Interest Parity: Empirical Evidence from Oceania” New Zealand Economic Papers, Vol. 45 No. 3: 209-229.

Habermeier, Karl; Kokenyne, Annamaria; Veyrune, Romain; Anderson, Harald (2009), "Revised System for the Classification of Exchange Rate Arrangements" IMF Working Paper: 1-18.

Hakkio, Craig S.; Rush, Mark (1989), "Market Efficiency and Cointegration: An Application to the Sterling and Deutschemark Exchange Markets", Journal of International Money and Finance, Vol. 8: 75-88.

Husted, Steven; Melvin, Michael (2013), International Economics, $9^{\text {th }}$ Ed., New Jersey: Pearson Education.

Ibrahim, Juliana; Long, Yasmiza; Ghani Hartini A.; Salleh S. I. M. (2011), "Weak-Form Efficiency of Foreign Exchange Market in the Organisation for Economic Cooperation and Development Countries: Unit Root Test", International Journal of Business and Management, Vol. 6 No. 6: 55-65.

Ingham, Barbara (2004), International Economics: A European Focus, London: Pearson Education.

Jeon, Bang N.; Lee, Euiseong (2002), "Foreign Exchange Market Efficiency, Cointegration, and Policy Coordination", Applied Economics Letters, Vol. 9 No. 1: 61-68.

Johansen, Soren (1988), "Statistical Analysis of Cointegration Vectors" Journal of Economic Dynamics and Control, Vol. 12 No.2-3: 231-254.

Kallianiotis, loannis N. (2013), Exchange Rates and International Financial Economics: History, Theories, and Practices, New York: Palgrave MacMillan.

Karfakis, Costas I.; Parikh, Ashok (1994), "Exchange Rate Convergence and Market Efficiency", Applied Financial Economics, Vol. 4 No. 12: 93-98.

Kim, Heeho; Cho, JooEun (2011), "A Test of the Revised Interest Parity in China and Asian Emerging Markets", Emerging Markets Finance \& Trade, Vol. 47 No. 4: 23-41.

Krugman, Paul R.; Obstfeld, Maurice (2009), International Economics: Theory and Policy, $8^{\text {th }}$ Ed., Boston: Pearson Education.

Lai, Kon S.; Lai, Michael (1991), "A Cointegration Test for Market Efficiency", The Journal of Futures Markets, Vol. 11 No. 5: 567-575.

Lee, Hsiu-Yun; Wu, Jyh-Lin (2004), “Convergence of Interest Rates Around the Pacific Rim”, Applied Economics, Vol. 36 No. 12: 1281-1288.

Levi, Maurice D. (2009), International Finance, $5^{\text {th }}$ Ed., New York: Routledge.

Lily, Jaratin; Kogid, Mori; Mulok, Dullah; Asid, Rozilee (2012); “Revisiting Uncovered Interest Rate Parity: An Empirical Testing Using Bounds Test Approach", Procedia Economics and Finance, Vol. 2: 45-52.

Lin, Chuang-Yuang; Wu, Ruey-Shan; Chen, Tsai (2010), “Taiwan's Foreign Exchange Market-Volatile But Still Efficient?”, Emerging Markets Finance \& Trade, Vol. 46 No. 1: 34-41.

Lobell, Hakan (2004), "Integration and Efficiency in the Foreign Exchange Market in Sweden 1834-1880", Scandinavian Economic History Review, Vol. 52 No. 1: 7-18.

Lothian, James R. (2016), "Uncovered Interest Parity: The Long and the Short of It", Journal of Empirical Finance, Vol. 36: $1-7$.

Markovsky, Petr (2014), "Modern Approaches to Efficient Market Hypothesis of FOREX-The Central European Case", Procedia Economics and Finance, Vol. 14: 397-406.

McDonald, Ronald (2007), Exchange Rate Economics: Theories and Evidence, New York: Routledge.

Melvin, Michael; Norrbin, S. C. (2013), International Money and Finance, $8^{\text {th }}$ Ed., Oxford: Elsevier.

Moosa, Imad A. (1996). "An Empirical Investigation into the Causes of Deviations from Covered Interest Parity Across the Tasman", New Zealand Economic Papers, Vol. 30 No. 1: 39-54.

Mylonidis, Nikolaos; Semertzidou, Maria (2010), “Uncovered Interest Parity Puzzle: Does It Really Exist?”, Applied Economics Letters, Vol. 17 No. 10: 1023-1026.

Omer, Muhammad; Haan, Jakob de; Scholtens, Bert (2014), “Testing Uncovered Interest Rate Parity Using LIBOR”, Applied Economics, Vol. 46 No. 30: 3708-3723.

Ozdemir, Nilufer (2013), "Market Structure, Excess Returns in the Foreign Exchange Market and Deviations from Uncovered Interest Parity", International Economic Journal, Vol. 27 No. 4: 587-608.

Ozdemir, Zeynel A. (2008): "Efficient Market Hypothesis: Evidence from A Small Open-Economy", Applied Economics, Vol. 40 No. 5: 633-641. 


\section{Eskişehir Osmangazi Üniversitesi ïiBF Dergisi}

Pesaran, Mohammad H.; Shin, Yongcheol; Smith, R. J. (1999), "Bounds Testing Approaches to the Analysis of Long Run Relationship", Edinburgh School of Economics, Discussion Paper Series, No. 46: 1-26.

Phillips, Peter C. B.; Perron, Pierre (1988), "Testing for A Unit Root in Time Series Regression”, Biometrika, Vol. 75 No. 2: 335-346.

Pilbeam, Keith (2006), International Finance, $3^{\text {th }}$ Ed., New York: Palgrave MacMillan.

Pugel, Thomas A. (2016), International Economics, $6^{\text {th }}$ Ed., New York: McGraw-Hill.

Sachsida, Adolfo; Roberto, Ellery Jr; Teixeira, J.R. (2001), “Uncovered Interest Parity and the Peso Problem: The Brazilian Case", Applied Economics Letters, Vol. 8, No. 3: 179-181.

Salvatore, Dominick (2013), International Economics, $11^{\text {th }}$ Ed., New Jersey: Wiley.

Sarno, Lucio; Taylor, Mark P. (2002), The Economics of Exchange Rates, UK: Cambridge University Press.

Sharpe, Ian G. (1984), “Covered Interest Rate Parity: The Australian Case”, Applied Economics, Vol. 16 No.5: 655-665.

Tang, Kin-Boon (2011), "The Precise form of Uncovered Interest Parity: A Heterogeneous Panel Application in ASEAN5 Countries", Economic Modelling, Vol. 28 No. 1-2: 568-573.

Ukpolo, Victor (1995), “Exchange Rate Market Efficiency: Further Evidence from Cointegration Tests”, Applied Economics Letters, Vol. 2 No.6: 196-198.

Visser, Hans (2004), A Guide to International Monetary Economics: Exchange Rate Theories, Systems and Policies, $3^{\text {th }}$ Ed., UK: Edward Elgar Publishing.

Wu, Jyh-Lin; Chen, Show-Lin (1998), "Foreign Exchange Market Efficiency Revisited”, Journal of International Money and Finance, Vol. 17: 831-838. 